\title{
On the status of functional categories (heads and phrases)
}

\author{
Guglielmo Cinque \\ Università Ca' Foscari (University of Venice)
}

In this article I would like to revisit one aspect of the structure of the functional sequence of the clause in light of certain recent developments, in particular Kayne's (2016) proposal that all heads are necessarily silent. I will also discuss the possibility that (certain) silent heads may be endowed with single features that denote complex notions taking progressive aspect as a case in point.

Keywords: functional categories, functional heads, phrases, progressive aspect

\section{Introduction}

In Cinque (1999) I had suggested that the AdverbP that corresponds to a certain functional verb in the extended projection of $\mathrm{V}$ (necessarily with respect to must as in (1a), possibly with respect to may, as in (1b), etc.) should be taken to be in the specifier position of the projection headed by the functional verb (which in certain cases may cross over it):

(1) a. This strategy [necessarily [must [consider a wider range of factors]]]

b. It may [ possibly [ [be worth the risk]]]

In retrospect, the idea was simplistic, in fact wrong, as shown by head-final languages (or constructions) where the AdverbP and the corresponding functional head morpheme (modal verb, restructuring verb, particle, etc.) can be separated by lower material raising between them:

(2) Er wird notwendigerweise [ein Buch schreiben] müssen (um die Position zu erhalten)

He will necessarily a book write ${ }_{\text {infinitive }}$ must (for the job to get)

'He will necessarily have to write a book (to get the job)' 
A possible way to retain the basic idea of Cinque (1999) is to assume the existence of paired functional projections separated by a silent one hosting moved constituents, arguably needed, as I discuss in Section 3, to derive the canonical word order of languages: ${ }^{1}$

(3)

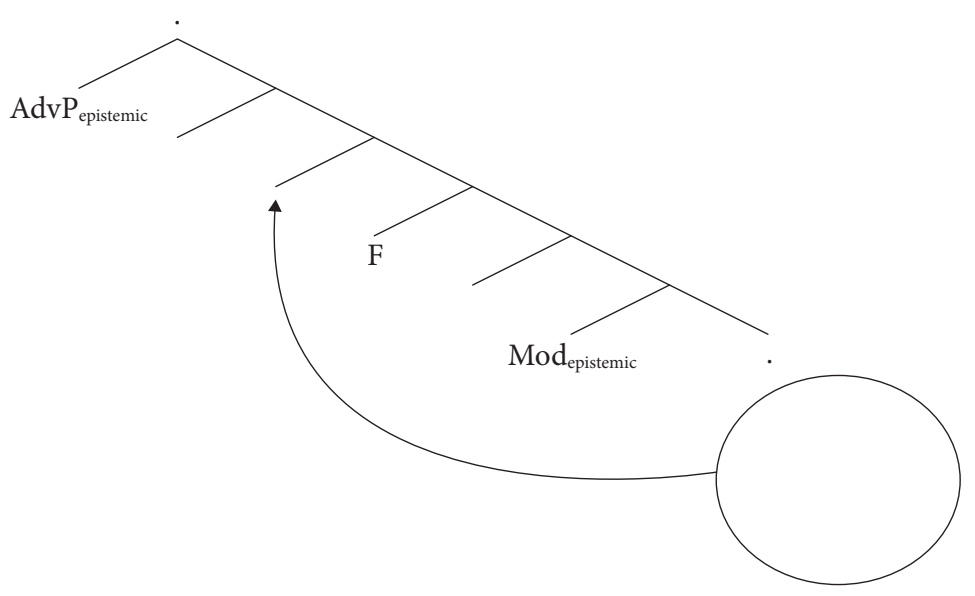

One of the paired projections (the lower one) represents the core functional notion, and the other (the higher one) an adverbial modification of the same functional notion. Languages may differ as to whether they lexicalize just the core functional projection (as in (4a)) or just the adverbial functional one (as in (4b)), or one or the other, or both together (as in (5)):

(4) a. I'-po'-pîtî-tu'ka-'pî-i-ya (Macushi - Abbott 1991: 113ff)

3-whip-ASP iter -ASP finally $^{-P A S T-3-E R G ~}$

b. he finally whipped him

(5) a. It may be worth the risk

b. It's possibly worth the risk

c. It may possibly be worth the risk

1. This silent projection resembles Nash \& Rouveret's (1997) notion of proxy category and Biberauer et al.s (2014: $\$ 4.3 .1$ ) caret feature (which they postulate for the derivation of headfinal languages) with "no semantic content, and no connection to phonological or morphological properties beyond simply causing movement" (p. 209). I have also come to think that the functional sequence has to be modified to make room for Williams' (2003:174) "subcycles" in specifier position (both for recursion of adjuncts like his (John let us down) every month every other year every decade.., and for 'sidetrack' functional sequences within the main one, like [altre [prime [due [NUMBER]]]] in [le [altre [prime [due [NUMBER]]]] domeniche] 'the other first two Sundays' - cf. Cinque (2015), though I cannot dwell on that here. 
Before addressing in Section 3 the issue of the derivation of head-initial and headfinal word orders, in Section 2 I briefly discuss the role of putative silent elements other than those recoverable under identity/non-distinctness. In Section 4 I will then consider one potential consequence of the more radical claim that all heads are necessarily silent and overt elements are phrases in the specifier of one such head.

\section{The double role of silence}

A number of recent works have accumulated evidence that there are syntactically represented, yet unpronounced, elements (in contexts distinct from classical deletion under identity): silent prepositions (Emonds 1996; Cinque 2010; Nchare \& Terzi 2014 and references cited there), certain silent verbs (van Riemsdijk 2002, 2012), silent auxiliaries (den Besten 1989), silent nouns (Kayne 2003b, 2004, 2005, 2006; van Riemsdijk 2002, 2003, 2005; Leu 2008), etc. Representative cases are listed in (6) and (7) (capitals indicate non-pronunciation):

(6) a. motion verb 'go':

.. wil merhetted söle häi GAA

..because we would've had-to home GO . .

(Swiss German - van Riemsdijk 2002, 2012)

'..because we should've gone home'

b. Auxiliary 'have': ..warum er geweint hat/HAT

c. Passive 'be':

(German - den Besten 1989: 60)

El vole ESSAR magnà (Basso Polesano - Benincà \& Poletto 1994: 49) it needs (to be) eaten

Trebuie A FI remarcat

(Romanian - GLR II: 752)

'It needs (to be) underlined'

d. Preposition to: The boat drifted TO/?to below the bridge

(Svenonius 2010: 130)

(7) a. at the age of seven YEARS/In THE YEAR 1955

b. Alle ORE una ORA HOUR (Kayne 2003b, Cinque 2011) at.theFEM.PL HOURS one HOUR

'at one o'clock'

c. DAG drie februari

DAY (De Belder 2007)

(day) three February

'the third of February'

d. Few NUMBER articles

NUMBER (Kayne 2005) 
e. John bought a green COLOR car yesterday. COLOUR (Kayne 2005)

f. Wat voor (een) TYPE musea heb je bezocht what for (a) museums have you visited?

TYPE (van Riemsdijk 2005)

'What kind of museums did you visit?'

g. ...dat Jantjes PERSON haar zou interesseren ...that Johnny's her should interest PERSON (Corver 2008) '...that Johnny should interest her'

h. He is from [THAT there PLACE] PLACE (Kayne 2004; Terzi 2010) etc.

Many types of common nouns can also be silent in the presence of the overt proper names that specify them:

(8) New York (city/CITY), The Mississippi (river/RIVER), The Mediterrenean (sea/SEA), etc.

Cases like (9) provide evidence that the common noun is present, even if unpronounced, because it can govern agreement. In Italian the proper name Il Cairo is masculine (witness the masculine article il), yet the participle in (9) shows feminine gender agreement, which can only be triggered by the silent noun CITTA' (the overt noun città in Italian is feminine).

(9) (LA CITTA' DE) il Cairo è stata, e resta, il centro più importante del mondo arabo

(Cinque 2011: 78)

(the city(fem.sg) of) the (masc.sg.) Cairo (masc.sg.) has been (fem.sg.), and remains, the most important center of the Arab world.

For all these cases, distinct from 'deletion under identity', I will use the term 'specified deletion/ellipsis' (van Riemsdijk 2003), originally used for the deletion of the generic object 'something', which derives unergative intransitives from transitives - eat something $\rightarrow$ eat $\varnothing$ (or 'eat' THING) (cf. Chomsky 1964: 42). ${ }^{2}$

How is the presence of such silent elements recovered? As van Riemsdijk (2003) notes there is no general theory of such kind of deletion.

The recovery of (MAKE) GO in German is possible only under specific conditions (which include a modal and an overt subject). Light/functional nouns or classifiers (Emonds's 1985 grammatical nouns) like those in (7), which constitute a closed and limited set (to the effect that each overt noun belongs to one or the other of such light/functional nouns or classifiers) are quite generally silent, as they are implicitly recoverable from the nouns they classify.

2. This deletion is possible in some languages (English, Italian, etc.) but not others (e.g. Mandarin, which must lexicalize the generic object: 'eat food/rice'). 
Silent common nouns are likewise plausibly recoverable as each proper name in (8) belongs to a certain common noun (New York belongs to the common noun 'city', Mississippi to the common noun 'river', etc.).

More recently, Kayne (2016) has advanced the radical conjecture that all heads are necessarily silent, overt material being merged as a phrase in specifier position of one such head. He argues that what were once taken to be overt head morphemes (complementizers, modals, particles, determiners, etc.) are actually phrases, where the single overt morpheme co-occurs with other silent elements, as shown in (10) (similarly for other traditional heads):

(10) a. Complementizers that, for: [that NP], [WHAT..for]

b. Modal V need: [HAVE $\left[_{\mathrm{NP}}\right.$ need $]$

c. Past suffix -ed in English [AT -ed(=THAT) TIME]

The phrasal character of the adverbial/modificational member of the paired functional projections in (3) is obvious, as adverbs can be modified.

(11) a. He may [very possibly] have to resign.

b. He must [almost necessarily] pretend that contests he loses in heavily black areas didn't happen.

Even when the adverbial/modificational member of the paired functional projections is a single morpheme, there is evidence that the structure is larger, with parts that are silent. See, for example, an adverb like long in English, in sentences like (12) (Kayne 2016: 26):

(12) Have you been waiting long?

Judging from (13), it is very plausibly the only overt exponent of a much more complex structure, approximately that in (14) (cf., again, Kayne 2016: 26): ${ }^{3}$

(13) a. Have you been waiting * (a) very long time

b. Have you been waiting for ${ }^{*}(a)$ long time

c. Have you been waiting for $\left({ }^{*} a\right)$ long

d. Have you been waiting for a (very) long time?

3. Similarly in Italian. See (i)

(i) a. (Ha aspettato) molto per molto/moltissimo tempo
per lungo tempo
molto a lungo $\left({ }^{\star}\right.$ tempo $)$
a lungo

b. (Ha aspettato) PER molto LUNGO TEMPO Lit. ((S)he waited) for a very long time 


\section{(14) Have you been waiting FOR A (VERY) long TIME?}

As Kayne (2016) argues, a phrasal character may be attributed even to those cases that we were used to consider functional heads, as the categories in (10) (what I referred to above as the core functional notions of the paired projections in (3)).

Does this mean that traditional aspectual categories like 'Progressive', 'Prospective,' 'Completive,', 'Habitual', etc., can be reduced to phrases containing some pronounced and some silent morphemes in the Spec of a silent head, and that we can dispense with them entirely, even as features of silent heads? While this cannot be excluded in principle, in Section 4 I will consider in some detail one case, that of the Progressive aspect, which proves instructive; for it seems not to lend itself, given the different morphological material that different languages co-opt to express it, to a unique periphrasis of overt and silent morphemes in Spec position, thus appearing to have to be encoded as a single complex feature on the silent head. Before addressing this question I consider in the next section the derivation of head-initial and head-final word orders which would seem to make a clear distinction between traditional (overt) functional heads and phrases, and see how it can be made compatible with the idea that all heads are invariably silent.

\section{The derivation of head-initial and head-final word orders}

In Cinque (2017), while exploring a micro-parametric (lexical) approach for what is often taken to be a macro-parameter, I suggested that we should preliminarily try to theoretically reconstruct the two ideal head-final and head-initial orders that transpire from the most rigid SOV and VOS languages, even if all languages depart from such ideal orders in one or more ways. The reason for taking that position is, I think, threefold: first, because fairly clear patterns, or at least clear tendencies pointing to such patterns, are recognizable, as already observed in the works of Greenberg (1963), Vennemann (1973), Lehmann (1978), Hawkins (1983) and Dryer (1992); second, because the reconstruction of such ideal orders and, in particular, the way in which they are derived may constitute a 'metric' on the basis of which one can measure the distance of each language from a 'standard', and in principle determine the place that each language occupies in the space of admitted variation (the fact that the 'standard' may be perfectly instantiated by no single language should not matter); third, because the Merge structure and derivational options admitted by UG may provide a plausible account of acquisition in that they yield a plausible account of how the child, on the basis of primary linguistic data can reconstruct the language particular options that derive his/her language (cf. $\$ 4.4$ of Cinque 2017). In the following sections I illustrate such 'ideal' orders 
only with the extended projection of the $\mathrm{V}$ (the clausal projection), ${ }^{4}$ and will for the sake of illustration use at first the traditional terminology of overt functional heads and phrases, to subsequently suggest a way to formulate the derivational options only in terms of phrases.

\subsection{The two ideal types}

\subsubsection{The "head-initial" type}

In the ideal head-initial order all higher (functional) heads precede VP in their order of Merge (with the higher more to the left), and phrasal specifiers (arguments, circumstantials, and modifiers) follow, in an order which is the reverse of their order of Merge (with the higher more to the right). See (15a) for a fragment of the extended projection of $\mathrm{V}(\mathrm{P})$ in a head-initial language and (15b) for an example from Anejom:
a. $\mathrm{C}^{\circ} \mathrm{T}^{\circ} \mathrm{Mod}^{\circ} / \mathrm{Asp}^{\circ} \mathrm{V}(\mathrm{P}) \mathrm{PP} / \mathrm{AdvP} \mathrm{DP} \operatorname{AdvP}$
b. Anejom
(Malayo-Polynesian, VOS - Lynch 1982: 119ff)
Is ika aen is pu apam imrañ
PAST say he PAST FUT come tomorrow
'He said he would come tomorrow'

\subsubsection{The "head-final" type}

In the ideal head-final order all higher functional heads follow the lexical $\mathrm{V}(\mathrm{P})$ in an order which is the reverse of the order of Merge (with the higher more to the right), and phrasal specifiers (arguments, circumstantials, and modifiers) precede $\mathrm{V}(\mathrm{P})$ in their order of Merge (with the higher more to the left). See (16a) for a representative fragment of the extended projection of $\mathrm{V}(\mathrm{P})$ in a head-final language, and (16b) for an illustrative example from Japanese:
a. $\operatorname{AdvP} \mathrm{DP} \operatorname{AdvP} / \mathrm{PP} \mathrm{V}(\mathrm{P}) \mathrm{Asp}^{\circ} / \mathrm{Mod}^{\circ} \mathrm{T}^{\circ} \mathrm{C}^{\circ}$
b. Watasi-wa [kare-ga osoraku sore-o zyoozuni okona-e-ru to] I-Top [he-NOM probably it-ACC well do-MOD-PRES COMP]

4. For a brief discussion of the extended projection of the N(P) I refer to Cinque (2017), from where the next sections draw many essential aspects. 


\subsubsection{The over-arching generalization}

The property which both the ideal head-initial and head-final word orders have in common is that whatever precedes the $\mathrm{V}(\mathrm{P})$ reflects the order of Merge, and whatever follows is in the mirror image of the order of Merge.

3.2 Deriving the two ideal word order types (with the segregation of heads and phrases)

The reason to consider the two orders as derived from a common hierarchy is that irrespective of the different orders of the same elements in the two types of languages (see (17a-b)) we would like to express the fact that the relative position and scope of these elements is the same, as represented in (18):

(17) head-initial

a. $\mathrm{C}^{\circ} \mathrm{Mod}^{\circ} \mathrm{V}$ AdvP $\mathrm{P}_{\text {manner }} \mathrm{AdvP}_{\text {epistemic }}$ head-final

b. $\mathrm{AdvP}_{\text {epistemic }} \mathrm{AdvP}_{\text {manner }} \mathrm{V} \operatorname{Mod}^{\circ} \mathrm{C}^{\circ}$

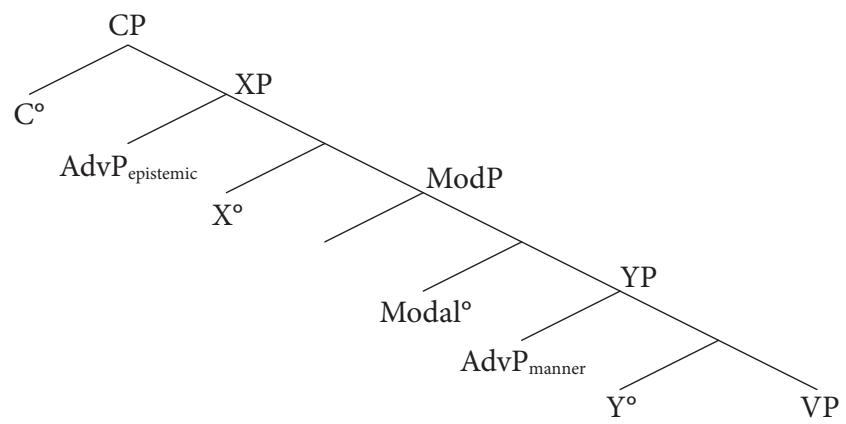

I thus take neither of the two orders in (17) to be more primitive than the other, but to derive from a common structure by blindly applying movement, in the way illustrated below, of the verbal projections in either of two ways: pictures-ofwhom pied piping, for head-final languages, and whose-pictures pied piping for head-initial ones.

While a symmetrical generation of the elements could easily capture the identical scope relations of (17) (cf. the simplified structures in (19)), a symmetrical generation could not capture the scope relations of certain other orders without violating the "No-Tangling" principle - see the case of (20): 
(19)

a. head-initial

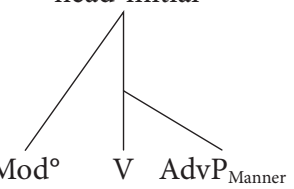

b.

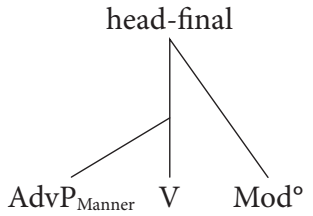

(20)

a.

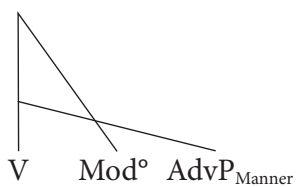

b. khun doong phoo phaasa thai dai nit-nooi

you must suffice speak Thai can a little (Thai-Duffield 1999: 118)

'You must be able to speak a little Thai.'

For (20), movement of VP, in (18), above $\mathrm{Modal}^{\circ}$ and $\mathrm{AdvP}_{\text {manner }}$ in one fell swoop seems to be the only option (but then movement may also derive what could be merged symmetrically, thus avoiding the redundancy of deriving some orders by both movement and base generation). ${ }^{5}$

I take (18) to be an antisymmetric spec $>$ head $>$ complement structure (Kayne 1994) terminating in (or rather originating from) a non branching VP, with complements of $\mathrm{V}$ merged in specifier positions above VP, to the effect that nothing is merged directly with V to its right, for reasons discussed in Cinque (2009). ${ }^{6}$

Despite the apparent segregation of traditional heads and phrases, which are found on opposite sides of the V, it looks as if the derivation of the two ideal orders

5. I assume that local reordering of morphemes (as in Distributed Morphology) should ideally be avoided. Also see Koopman (2015a, b) for arguments that the same 'computational engine' (phrasal movement within an antisymmetric Merge structure) underlies both narrow syntax and word formation.

6. Namely, to capture the pervasive left-right asymmetry of natural languages. This will also require a different way to distinguish '(subcategorized) complements' from 'non-complements'. For some discussion see Cinque (2004: note 19, and relative text).

The present proposal shares with Haider (1992, 2013 Chapter 3) and Barbiers (2000) the idea that the Merge structure of clauses originates from $V$ and is strictly right branching, though it differs from them in assuming that movement is involved in deriving both head-initial and head-final languages, in the ways sketched below. 
can be implemented even if every overt constituent (including 'traditional' heads: auxiliaries, modals, complementizers, etc.) is taken to be a phrase merged as the specifier of a silent head. What appears to make a difference between traditional heads (which will now be specifiers of a silent head) and traditional phrases is that only the (silent) head of the former 'selects' a category of a distinct type.

To briefly give ahead the basic idea, the different assumptions involved in the derivation of the two hierarchies (ultimately orders under the LCA) are the following (illustrated in Section 3.2.1 with the head-initial type and 3.2.2 with the head-final one): ${ }^{7}$

a. VoicePs, AspPs, TPs, ModPs, MoodPs, CPs for the verbal extended projection (the clause) are the functional projections which (1) label the Syntactic Object (SO) in $\{\mathrm{XP}, \mathrm{YP}\}$ instances of Merge; ${ }^{8}$ (2) select one of the other functional phrases, attract it in the whose-pictures pied piping mode (yielding the ideal head-initial type) or the pictures-of-whom piedpiping mode (yielding the (ideal) head-final one), and then move with the same pied piping mode. ${ }^{9}$

7. These will be based for simplicity on traditional X-bar representations, where only the higher segment will be labeled: $\left.\left.{ }_{\mathrm{FP}} \mathrm{XP}[\mathrm{F}]\right]\right)$. As far as I can see, the Merge and Move derivations to be proposed are compatible with Kayne's (2016) idea that heads are necessarily silent, and potentially also compatible with a system adopting Merge and Labeling, as that presented in Chomsky (2013) and Rizzi (2016).

8. This is a minimal extension of the labeling conventions of Chomsky (2013) and Rizzi (2016) in a system like that of Kayne (2016), where all heads are silent, and yet the segregation of traditional functional 'heads' and traditional phrases in the (ideal) head-initial and head-final languages has to be captured.

9. Here I assume a version of the traditional notion of pied piping (Ross 1967: $₫ 4.3$ ), "whereby some particular movement operation $\mathrm{T}$, designated to displace an element $\mathrm{A}$, ends up moving some constituent B that properly contains A." (Horvath forthcoming: Section 1). There are essentially two types. In one (the whose-picture pied piping type), A, the constituent that drives the movement, is the highest specifier of $\mathrm{B}$, the larger constituent that moves. In the other (the pictures-of-whom pied-piping type), A, the constituent that drives the movement, is the lowest phrase of $\mathrm{B}$, the larger constituent that moves. It is sometimes assumed that the larger constituent $\mathrm{B}$ inherits, by upward percolation, the feature of A that drives the movement. Here what drives the movement is not he $w h$-feature but, we may assume, the $+\mathrm{V}$ feature borne by the verbal functional projections mentioned in (21a). Later we shall see that the pictures-of-whom pied-piping is possibly more marked than the whose-picture pied piping. Later I also consider a third (apparently even more marked) type of movement: that of the nucleus (VP or NP) without pied piping, which yields such "less popular" (Greenberg 1963: 87) orders as N Dem.Num A and V Mood Tense Aspect (Cinque 2014: 238f). Pied piping is generally optional (unless required to prevent some violation, e.g. of the Left Branch Constraint). In the derivation of all word orders except the "less popular" ones just mentioned it is however obligatory; something that remains 
b. the paired non core adverbial projection of the core projections VoiceP, AspP, etc. is merged on top of the core one after the movements of the selected projection and of the core one.

Let us then consider the two cases in turn (needless to say, at this stage, any proposal can only be programmatic in character, and tentative).

\subsubsection{The "head-initial" type}

Recall the generalization concerning the "head-initial" word order type: all higher (functional) heads precede $\mathrm{V}$ in their (hierarchical) order of Merge, and phrasal specifiers (arguments, circumstantials, and modifiers) follow $\mathrm{V}$ in an order which is the reverse of their (hierarchical) order of Merge. See the simplified (22):

$$
\mathrm{C} \mathrm{Mod}_{\text {epistemic }} \mathrm{V} \text { AdvP } \mathrm{manner} \mathrm{AdvP}_{\text {epistemic }}
$$

The order in (22) can be derived as illustrated in (23) through (25). First VP moves with (vacuous) whose-pictures pied piping above the (object) DP, and labels the new SO as VP (by (16a1)); then the next functional projection selecting VP (say, VoiceP) is merged, and labels the new SO VoiceP (by (16a1)). This is followed by movement of the selected VP and by the subsequent movement of VoiceP with the same pied piping mode (by (16a2)):

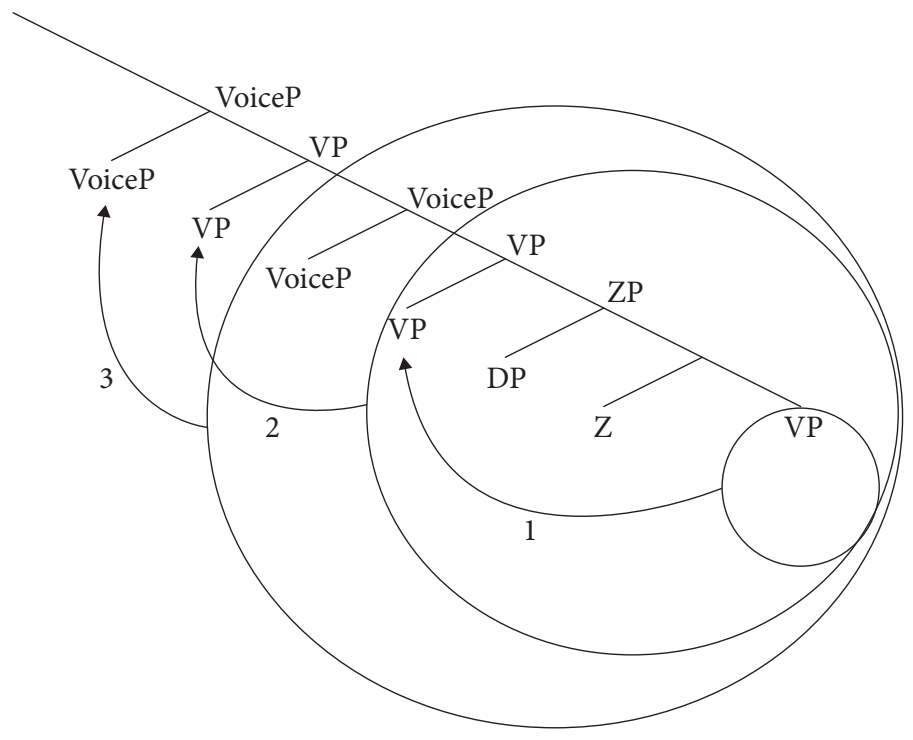

to to be understood. For insightful discussion of classical pied piping and more recent alternative formulations which do away with feature percolation, see Horvath (forthcoming). 
This generalizes Kayne’s $(1999,2003 \mathrm{a}$ : $\$ 4.5)$ derivation of the infinitival complementation of (functional) verbs like try in English, which restores the original hierarchical relation between the functional and the lexical verb (also see Koopman \& Szabolcsi 2000):

(24) a. try leave (merger of $\mathrm{K}) \rightarrow$

b. K try leave (movement of InfinP to Spec,K) $\rightarrow$

c. leave ${ }_{\mathrm{i}} \mathrm{K}$ try $\mathrm{t}_{\mathrm{i}}$ (merger of $\left.\mathrm{P} / \mathrm{C}\right) \rightarrow$

d. to leave ${ }_{\mathrm{i}} \mathrm{K}_{\text {try }} \mathrm{t}_{\mathrm{i}}$ (movement of VP to Spec,P/C) $\rightarrow$

e. $\quad\left[\text { try } t_{i}\right]_{j}$ to leave ${ }_{i} \mathrm{Kt}_{j}$

At this point the non core adverbial projection paired with VoiceP, $\mathrm{AdvP}_{\text {MannerVoice }}{ }^{10}$ is merged, followed by movement of VoiceP above it in the whose-pictures pied piping mode, and labeling of the new SO as VoiceP, as shown in (25a):

a.

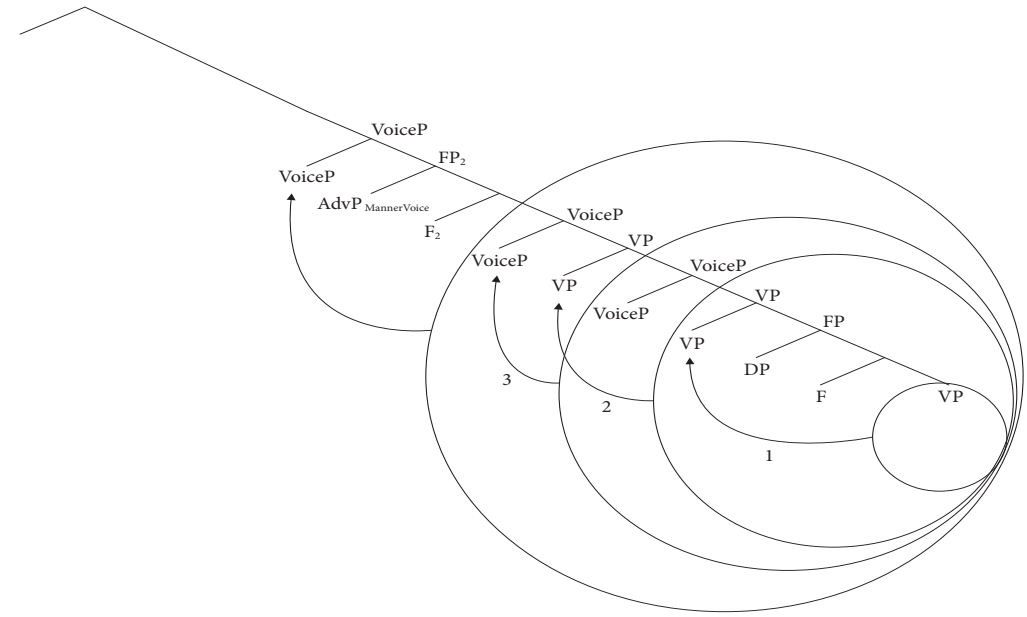

The order that the LCA would obtain from the hierarchical structure built so far is V DP AdvP ${ }_{\text {manner }}$

At this point the functional projection selecting VoiceP (let's say ModP $\mathrm{epistemic}$ for simplicity) is merged, followed by movement with whose-pictures pied piping of VoiceP above it and movement with whose-pictures pied piping of $\mathrm{ModP}_{\text {epistemic }}$ above VoiceP, restoring their respective hierarchical position. After that the non core adverbial projection paired with $\mathrm{ModP}_{\text {epistemic }}\left(\mathrm{AdvP}_{\text {epistemic }}\right)$ is merged, followed by movement of $\mathrm{ModP}_{\text {epistemic }}$ above it:

10. Cf. Chomsky's "generalization that relates Manner Adverbials to passivization" (Chomsky 1965: 218 note 28) (i.e. "the restriction of passivization to Verbs that take Manner Adverbs freely”- Chomsky 1965: 104). 
(25) b.

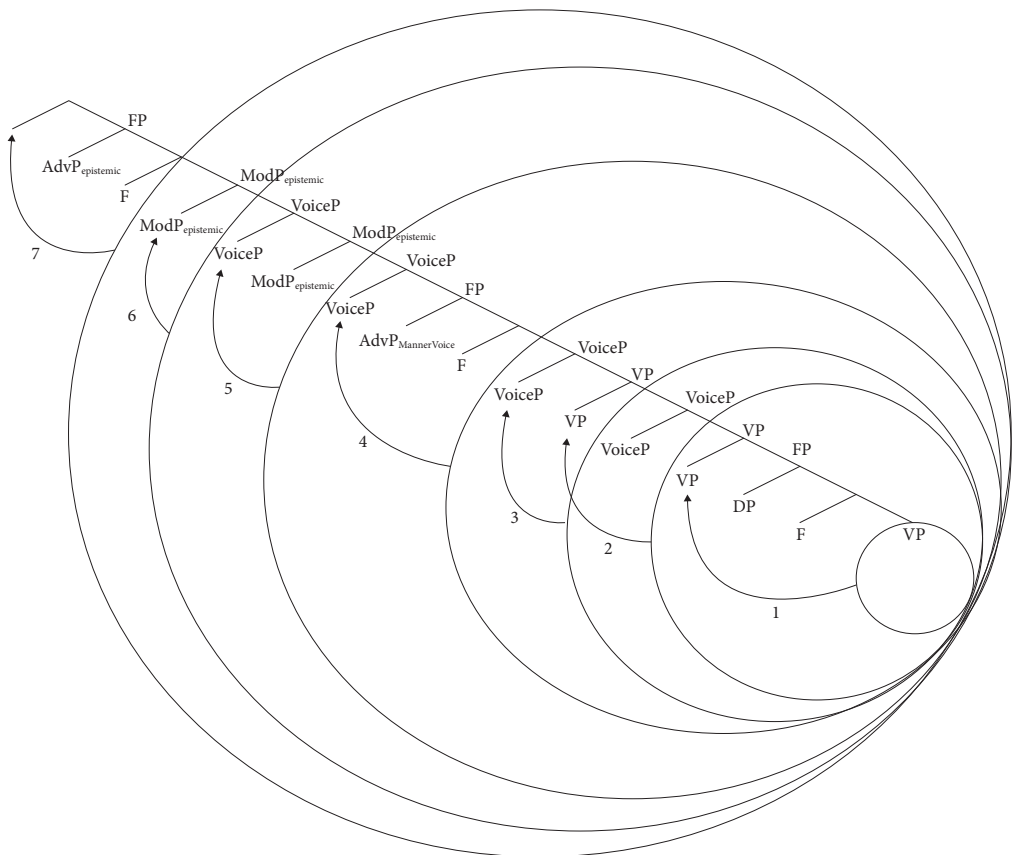

From the hierarchical structure so far built the order that the LCA would yield is $\mathrm{Mod}_{\text {epist }} \mathrm{V}$ advP $\mathrm{P}_{\text {manner }} \operatorname{advP}_{\text {epistemic }}$, which corresponds closely to the order of elements in the VSO language Peñoles Mixtec (modulo PAST for ModP ${ }_{\text {epist }}$ ). See (26): ${ }^{11}$

11. If movement obtains without pied piping (an option that is also available in some languages - cf. fn.9) the illusion is created that a head may cross over another head in apparent violation of the 'Head Movement Constraint'. This may be welcome for those languages (like Bulgarian) which appear to move an auxiliary over a higher one, in so called "Long Head Movement", presumably to an Ā-position (i) (cf. Embick \& Izvorski 1995):

(i) Bil $_{\mathrm{i}}$ săm $t_{\mathrm{i}}$ kupil knigata

been am.I bought book.the

'I have allegedly bought the book'

The movement of the second auxiliary (phrase), bil 'been', in (i), is one of the ways in which one can satisfy the requirement that the clitic auxiliary săm not be in first position (other options consist in having another phrase precede it, with different pragmatic effects (cf. Lambova 2004: Chapter 5), as in (ii)):

(ii) a. Az săm bil kupil knigata

I am.I been bought book.the

b. kupil săm bil knigata

c. knigata săm bil kupil

'I have allegedly bought the book' 
(26) ní šitu ba?a na?i-d

PAsT plow well probably-he

'He probably plowed well'

Next, CP is merged, which I take for simplicity to select ModP epistemic $_{\text {, and the }}$ same movements eventually yield the overall order $\mathrm{C} \mathrm{Mod}_{\text {epistemic }} \mathrm{V}$ AdvP ${ }_{\text {manner }}$ $\mathrm{AdvP}_{\text {epistemic }}$ which appears to be the order of consistent head-initial languages. ${ }^{12}$

\subsubsection{The ideal "head-final" type}

Recall the generalization concerning the ideal head-final word order type: all higher (functional) 'heads' follow the lexical $\mathrm{V}$ in an order which is the reverse of the (hierarchical) order of Merge, and phrasal specifiers (arguments, circumstantials, and modifiers) precede $\mathrm{V}$ in their (hierarchical) order of Merge

The functional projections of the ideal "head-final" languages move with the pictures-of-whom pied-piping. Starting from a Merge structure like (18), the order in (17b) can be achieved as indicated in (27). ${ }^{13}$

After the merger of the complement DP, VP labels the dominating projection FP by percolating its label under the pictures-of-whom pied piping mode. Then VoiceP is merged and VP is attracted above it, after which VoiceP percolates its label to VP under the pictures-of-whom pied piping mode and moves labeling the new projection as VoiceP:

12. Subject, complements, and circumstantial DPs, which I take to be merged above VP in the order $\mathrm{DP}_{\text {time }} \mathrm{DP}_{\text {location }} . . \mathrm{DP}_{\text {instrument }} . . \mathrm{DP}_{\text {manner }} \mathrm{DP}_{\text {agent }} \mathrm{DP}_{\text {goal }} \mathrm{DP}_{\text {theme }} \mathrm{V}^{\circ}$, in head-initial languages surface in the reverse order, abstracting away from optional focus movements, shown in (i), owing to the roll-up derivation (after raising to higher licensing positions). See Cinque (2017).

(i) $\mathrm{V}^{\circ} \mathrm{DP}_{\text {theme }} \mathrm{DP}_{\text {goal }} \mathrm{DP}_{\text {agent }} \mathrm{DP}_{\text {manner }} . . \mathrm{DP}_{\text {instrument }} . . \mathrm{DP}_{\text {location }} \mathrm{DP}_{\text {time }}$

It is interesting to note that virtually the same order/hierarchy of (i) appears to hold DPinternally in English complex nominals (Rae 2009) and, modulo the mirror-image order, with Romance relational adjectives (Bortolotto 2015), pointing to deep seated scope relations among these arguments and circumstantials.

13. This generalizes the derivation of agglutinative morphology in head-final languages sketched in Kayne (1994: $\$ 5.5)$ :

$$
\ldots X\left[_{\mathrm{YP}} \ldots \mathrm{Y} \mathrm{ZP}\right] \ldots \rightarrow \ldots \mathrm{X}\left[_{\mathrm{YP}} \mathrm{ZP} \mathrm{Y} \mathrm{t} \mathrm{t}_{\mathrm{ZP}}\right] \ldots \rightarrow\left[_{\mathrm{YP}} \mathrm{ZP} \mathrm{Y} \mathrm{t} t_{\mathrm{ZP}}\right] \mathrm{Xt}_{\mathrm{YP}}
$$


(27) a.

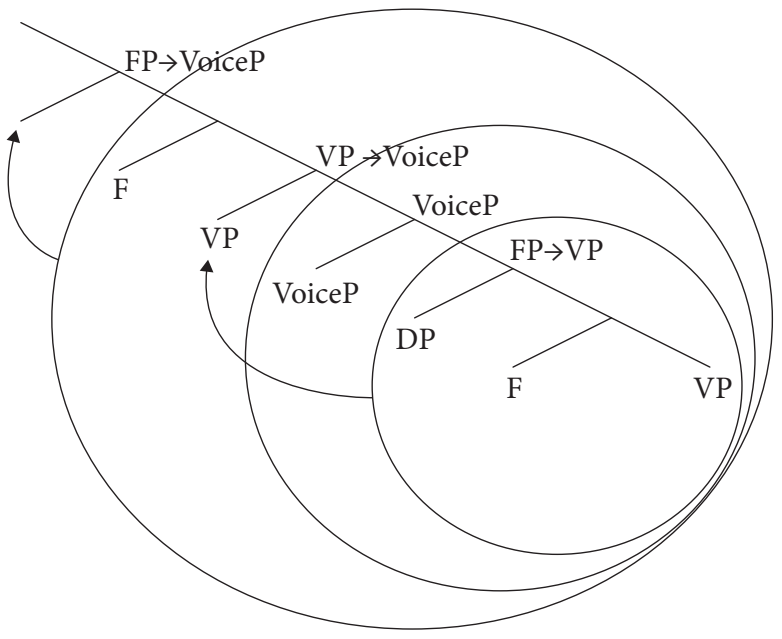

This step is followed by the merger of the non core adverbial projection paired with VoiceP, namely $\mathrm{AdvP}_{\text {MannerVoice, }}$ after whichVoiceP percolates its label under the pictures-of-whom pied piping mode:

(27) b.

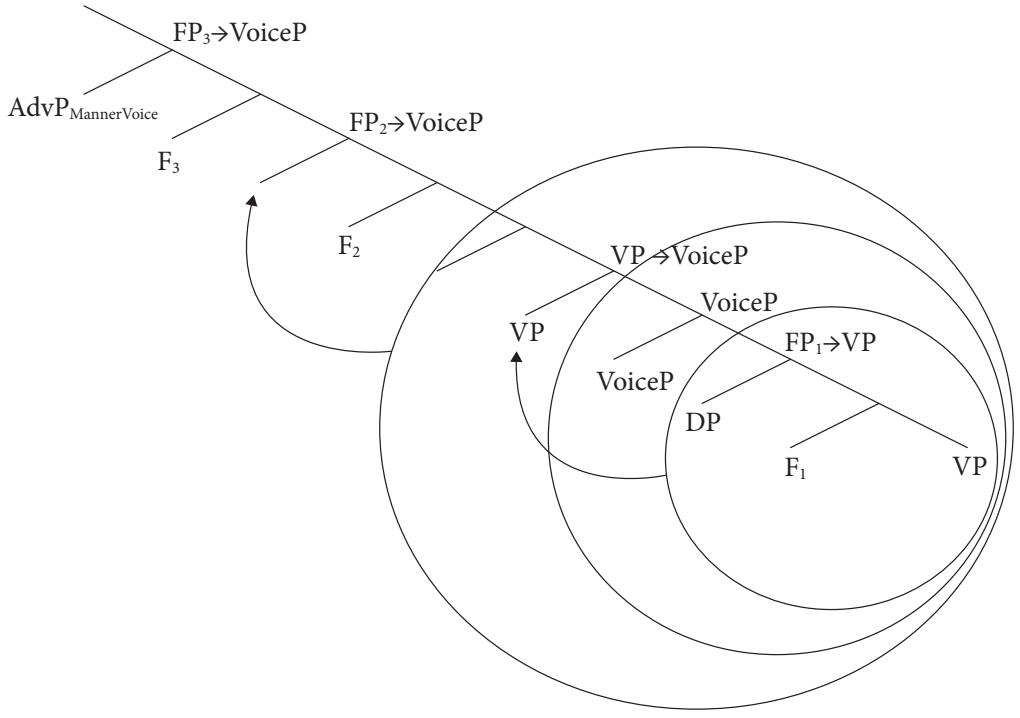

Next the functional projection selecting VoiceP, say, again, $\mathrm{ModP}_{\text {epistemic }}$, is merged and VoiceP is attracted above it: 
(27) c.

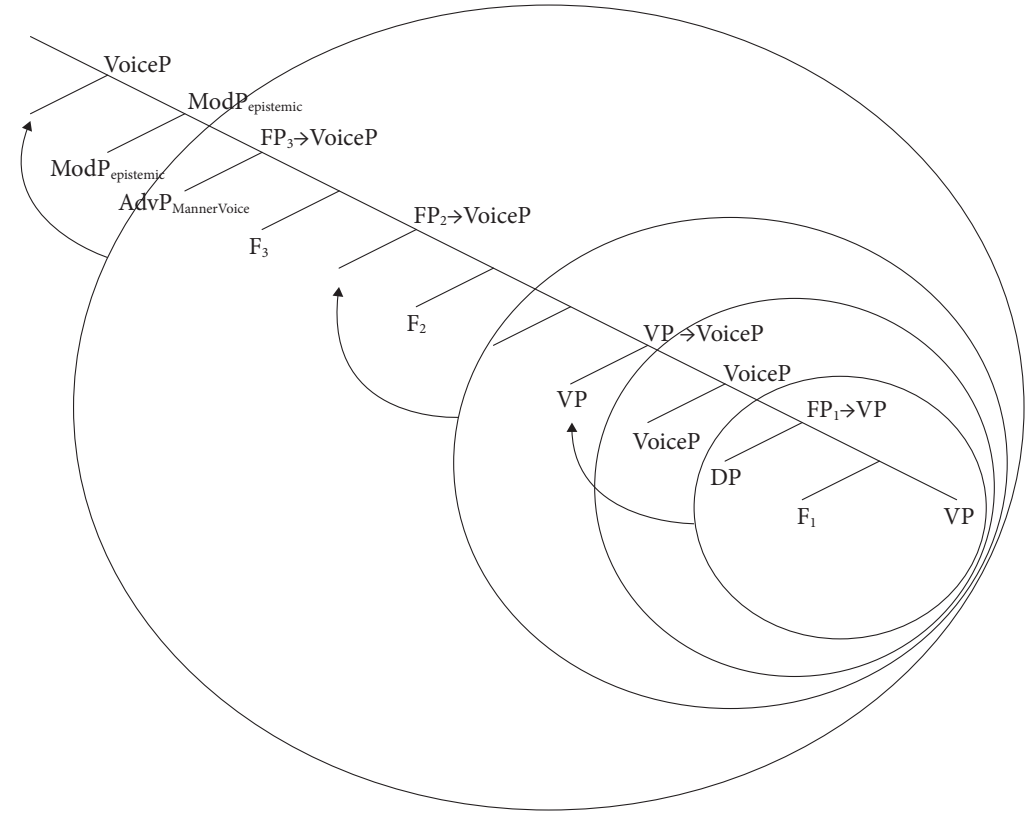

After that ModP ${ }_{\text {epistemic }}$ percolates its label to VoiceP followed by merger of the non core adverbial projection paired with it, $\mathrm{AdvP}_{\text {epistemic }}$ Once the next higher selecting functional projection $\mathrm{CP}$ is merged $\mathrm{ModP}_{\text {epistemic }}$ is attracted above it in the pictures-of-whom pied piping mode, followed by the percolation of the CP label and movement of $\mathrm{CP}$ with the pictures-of-whom pied piping mode:

(27) d.

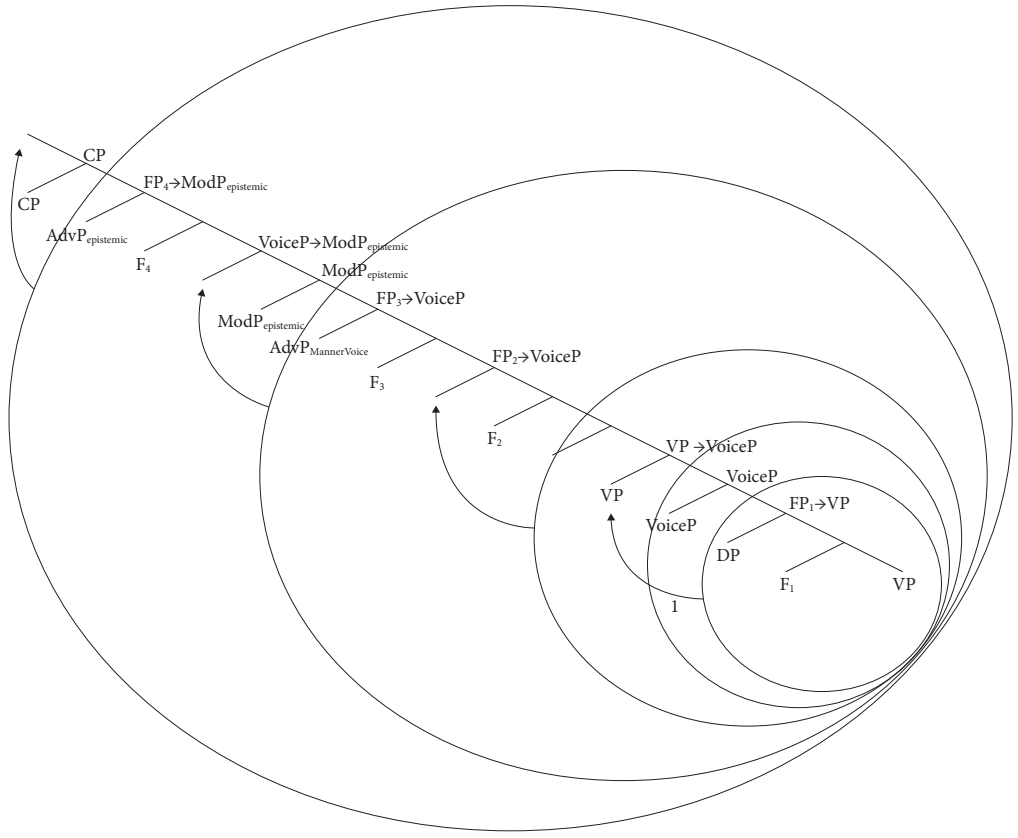


Under the LCA this derivation yields the linear order in (28), with segregation of the modifier verbal phrases (in their order or Merge) to the left of $\mathrm{V}$, and of the 'heads' (or rather the corresponding phrasal projections) to the right of V. Cf. the Japanese example in (16b), repeated here as (29):

(28) $\mathrm{AdvP}_{\text {epistemic }} \mathrm{AdvP}_{\text {manner }}$ DP V Mod epistemic $\mathrm{C}$

(29) Watasi-wa [kare-ga osoraku sore-o zyoozuni okona-e-ru to] I-Top [he-NOM probably it-ACC well do-Mod-Present that] it-ta. say-PAST

'I said that probably he can do it well'

My tentative conclusion then is that heads can indeed be silent across the board (as in Kayne 2016), and that the apparent segregation of the traditional functional heads on one side of VP and of argumental, circumstantial and adverbial phrases on the other, can be achieved by distinguishing core functional projections (what we were used to call heads) from the non core adverbial projections paired with them, arguments and circumstantial PPs.

Actual languages depart from these ideal derivations to different degrees, mixing movements with whose-pictures and pictures-of-whom pied piping, as well as movement without pied piping, at different points of the derivation.

\section{Are there features encoding complex notions?}

In this section I return to the issue whether silent heads can be endowed with features denoting complex notions examining one such case: that of Progressive aspect.

\subsection{Some notes on Progressive aspect}

Progressive aspect refers to an activity which takes place at a certain time point or interval contained within a larger time interval where the same activity takes place (cf. Montague 1970; Bennett \& Partee 1972; Dowty 1979; Dahl 1985: 91; Higginbotham 2004; Ramchand \& Svenonius 2014, and references cited there). See Bennett \& Partee's (1972) characterization in (30), taken from Dowty (1979: 145), which formalizes Jespersen's (1924: 277ff) basic insight that Progressive aspect is "a temporal frame encompassing [some reference time]". Cf. (31)). 
(30) $[$ PROG $\phi]$ is true at interval I iff there exists an interval I' such that I $\subset \mathrm{I}$, I is not a final subinterval of I', and $\phi$ is true at I.' ${ }^{14}$

a.

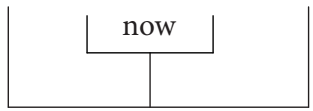

b.

he is sleeping

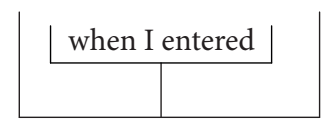

he was sleeping

Characteristically Progressive aspect is said to be fine with Vendler's (1957) activities ('he is running') and accomplishments ('He is writing a report') and bad with (permanent) states ('We are being mortal', 'He is knowing that we are here'), instantaneous achievements ('He is finding a wallet'), as well as with verbs used performatively ('I am declaring open the Olympic Games'). ${ }^{15}$ With achievements that have preparatory stages ('He is reaching the top'; 'The plane is landing'; 'John is leaving, 'He is winning', etc.) Progressive aspect appears to apply to the stages that precede the final achievement thus resulting in a Prospective aspect interpretation ('He is about to reach/on the verge of reaching the top', etc. - on the latter aspect see Comrie 1976: $\$ 3.3$ ); ${ }^{16}$ with semelfactives ('The door is banging'; 'John is coughing'), Progressive aspect is instead coerced to an Iterative aspect interpretation (Comrie 1976: 42).

With Binnick (1991:282) I will be assuming, perhaps not innocently, that Progressive aspect is a universal category. If we consider actual languages this

14. (30) must be supplemented with the condition that $\phi$ must constitute an activity. For refinements of the semantic characterization of Progressive aspect, see Bhatt \& Pancheva's (2005a, b) and Portner's (2011) surveys of the rich literature.

15. Less sharp is the case of imperatives, which are often bad in the progressive periphrasis: ${ }^{\star}$ Sta (i) lavorando! 'Be working!', ${ }^{\star}$ Sta (i) mangiando tutto! 'Be eating everything!' (cf. Bertinetto 1986: 138), although acceptable examples are occasionally cited in the literature on English (for whose acceptabilty an explicit reference time is apparently crucial):

(i) a. Be working hard when he returns!

(Haegeman 1982: 16)

b. Be sitting there when I get back

(Frajzyngier et al. 2008: $\$ 7$ )

16. Also see Smith (1997: 97), Dini (2002: $\$ 1.3$ ), and Timberlake (2007: 287ff). The Chinese progressive marker $z a i$ is however incompatible with achievement verbs that have preparatory stages (cf. ${ }^{\star}$ Lao Wang zai si 'Old Wang is dying' - Smith 1997: 272). Interestingly, in Thai with such verbs the Progressive aspect particle kamlay has to co-occur with the Prospective (Imminential) aspect particle $c \grave{a}^{\text {}}$, in the order kamlay $c \dot{a}^{\text {' }}$ (Srioutai 2005: 222; Cinque 1999: 75, 159, and 209 note 63). It is tempting to think that in English (and Italian), though not in Chinese, a silent prospective morpheme corresponding to the Thai particle $c \dot{a}^{\text {? }}$ is activated. 
assumption appears immediately dubious as there are syntactic differences in the syntax of the progressive aspect periphrases between, say, English and Italian (cf. (32)) $)^{17}$

(32) a. He was being interrogated by the police $a^{\prime} .{ }^{*}$ Lui stava essendo intervistato dalla polizia

b. He is being naughty

$\mathrm{b}^{\prime} .{ }^{\star}$ Lui sta essendo cattivo

c. They have been fishing for 3 hours

$c^{\prime} .{ }^{*}$ Loro sono stati pescando per 3 ore

d. The book is lying on the table

$\mathrm{d}^{\prime} .{ }^{\star}$ Il libro sta giacendo sul tavolo

e. He is living in Texas

$\mathrm{e}^{\prime} .{ }^{*}$ Lui sta vivendo in Texas

f. He is always drinking whisky

$\mathrm{f}^{\prime}$. ${ }^{\star}$ Lui sta sempre bevendo whisky

and even within different varieties of English (cf. (33)); almost certainly between any two languages.
a. ${ }^{*}$ I was not knowing
these
facts.
(Standard English)
$a^{\prime}$. I was not knowing
these facts. (Indian (and other variants
of) English) ${ }^{18}$
(Schubert 2002: 25)

17. The French progressive periphrasis appears to be closer to the Italian than to the English progressive periphrasis (see for Example Laca 2004: \$3.2; Leeman 2012: 133; De Wit et al. 2013), although it seems to also be able to cover the Prospective aspect: La terre est en train d'être frap-

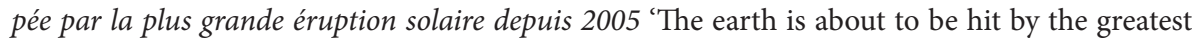
solar eruption since 2005', which is rendered by a different periphrasis in Italian (cf. sta per essere colpita 'is about to be hit..' ${ }^{*}$..sta essendo colpita 'is being hit'. It also differs from Italian in the possibility of using en train de in a reduced relative clause (A cette heure-ci, il y a des tas de gens en train de comprendre que c'est un homme vraiment dangereux vs. It. *A quest'ora c'è un sacco di gente ${ }^{*}$ (che sta) comprendendo che è un uomo veramente pericoloso 'At this time there are lots of people (who are) understanding that he is a truly dangerous man'). I am not considering the futurate use of the progressive (Dowty 1979: 154ff; Haegeman 1982; Smith 1983: 496; Bertinetto 2000: $\$ 6.2 .3$ ), which is good in English but bad in both Italian and French (Tomorrow I'm taking her to the zoo. vs. (It.) ${ }^{\star}$ Domani sto portandola allo zoo; (Fr.) ${ }^{\star}$ Demain je suis en train de l'emmener au zoo (de Wit \& Patard 2012: 2).

18. On Irish English, see Filppula (1999: 89) who states that the progressive form can also be used with verbs like 'want', 'know', 'belong', and other verbs which cannot enter the progressive periphrasis in standard English. On Black South African English, which also extends the 'be + V-ing' periphrasis to statives, see Piotrowska (2014). For such 'extended progressives' in other English dialects see Gold (2007: \$3) and references cited there. 


\section{b. * Are you wanting anything? (Standard English) \\ $\mathrm{b}^{\prime}$. Are you wanting anything? (Indian (and other variants of) English)}

(Schubert 2002: 25)

Despite this evidence, I want to believe that we do not have to abandon the hope of substantiating, in this as in other cases, the existence of universal categories holding across languages (in UG). Hopefully, the discrepancies that we find here, and elsewhere, will turn out to depend on the fact that different languages cut the cake in different ways, some of them, for example, using one and the same morphological exponent/periphrasis to express more than one aspectual category. Crucial is the distinction between universal categories and the way they are morphologically expressed. Consider the extreme case of Bulgarian, which has no special progressive form (pace Kuteva 1999), ${ }^{19}$ and uses the present (inherently imperfective) (34), or the past imperfective (35), to convey what in English would have to be expressed either with the progressive ((Pres or Past) be $+V$-ing) periphrasis (36a-b) for on-going processes or, for stative/habitual meanings, with the Present or the Past, or the used to periphrasis (37a-b):

(34) V London vali mnogo In London rains a lot

a. 'In London it's raining a lot'

(present progressive)

b. 'In London it rains a lot' (present generic/habitual)

(35) V London valeše mnogo

a. 'In London it was raining a lot' (past progressive)

b. 'In London it rained/used to rain a lot' (past generic/habitual)

(36) a. In London it's raining a lot

(present progressive)

b. In London it was raining a lot

(past progressive)
a. In London it rains a lot
b. In London it rained/used to rain a lot

(present generic/habitual)

(past generic/habitual)

19. Kuteva (1999) claims that the postural verbs 'sit'/'stand'/'lie' have come to express in Bulgarian the continuative/durative/progressive aspects, saying that while "this structure has remained largely unnoticed by analysts of the language, in other languages such as NorthGermanic it has been treated by some authors as Aktionsart periphrasis". This is however dubious given the ungrammaticality of ${ }^{\star}$ Kogato ti doide, toj ležese $i$ speše 'When you came in, he was lying and sleeping' to just mean 'he was sleeping', and more clearly that of ${ }^{\star}$ To sedi/stoj/lezi $i$ vali 'It sits/stands/lies and rains' to mean 'it's raining' (Iliyana Krapova, p.c., who also tells me that for her such periphrases with 'sit/stand/lie', as Toj veče dva časa sedi i čete, have the literal meaning 'He sat and read for two hours.'). 
Italian and French are partly similar to Bulgarian. Although they have a progressive periphrasis (stare $+\mathrm{V}_{\text {gerundive }}$ and être en train de $+\mathrm{V}_{\text {infinitive }}$ ), the simple present and the past imperfect forms can apparently substitute for the progressive aspect periphrasis (see (38)-(39)): ${ }^{20}$
a. Guarda! Piove/sta piovendo
Look! It.rains/it.stays raining
'Look! It's raining.'
b. Lo senti? Urla/sta urlando; russa/sta russando Him hear.you? He shouts/He stays shouting; He snores/He stays snoring 'Can you hear him? He is shouting/He is snoring'
a. $\quad$ Il pleut/Il est en train de plevoir $^{21}$
It rains/It is in the course of rain infinitive $_{\text {in }}$ 'It is raining'
We ate/We
'We were eating'
were in the course of eat ${ }_{\text {infinitive }}$
b. Nous mangions/Nous étions en train de manger

In view of this, I don't think it would be rational to claim that Bulgarian lacks the Progressive aspectual category (especially if one brings in Italian and French, which can be like Bulgarian but also have a progressive aspect periphrasis). More sensible would be to say that to express Progressive aspect Bulgarian uses a morphological form that can also express the Generic and Habitual aspects, thus neutralizing at the morphological level the grammatical distinction (or distinctions, if more aspects are actually covered by the same form).

This boils down to the observation that there is no necessary one to one relation between morphological 'forms' and, in the case at hand, 'aspectual meanings', a well-known observation (Bertinetto et al. 2000: 532; Bhatt \& Pancheva $2005 \mathrm{a}, \mathrm{b}$ ). One form can come to express more than one aspectual meaning (the Bulgarian, as well as the Italian and French, Present and Past Imperfect expressing the Generic, Habitual, and Progressive aspects) ${ }^{22}$ and one and the same meaning (Progressive aspect) can come to be expressed by more than one form (Italian

20. See Comrie (1976: 33) and for French Mortier (2008: $\$ 3.1$ ).

21. Copley \& Roy (2013) (also see Leeman 2012) claim that the être en train de periphrasis has in many cases an associated pejorative meaning, so that $I l$ est en train de plevoir becomes more natural if sur notre pique-nique is added, with the meaning 'It's raining on our picnic (and the picnic is ruined)' (Section 1).

22. Also see the case of those languages where the same form expresses both the Progressive and the Perfect aspects (depending on the Aktionsart of the verb - Ebert 1995). 
and French Present/Past Imperfect and the progressive periphrasis in the Present or Past Imperfect).

In principle each aspectual category ought to be precisely defined, so as to predict its compatibility with different verb classes and adverbials. That one and the same form can come to express more than one aspect plausibly depends on the fact that these aspects have a common core and differ with respect to one or more conditions. So for example the Progressive, the Habitual and the Generic aspects (which apparently occupy different positions in the functional sequence of the clause - cf. Cinque 1999), plausibly have a common core meaning. Each contains the minimal specification that it holds at the utterance time ('now'), or at a reference time in the past or the future ('then'). They would then differ as to other facets of their meaning, the Progressive containing further and more stringent requirements on top of the shared core (e.g. limitation to activities, limited time span, etc.). The Bulgarian present morphology could then be seen as maximally underspecified, encoding overlap with 'now', without encoding the further conditions that characterize and distinguish among them the Generic, the Habitual or the Progressive aspectual categories (see below for a possibly more correct analysis involving the presence of a silent Progressive aspect projection even in Bulgarian, still compatible with the above idea of underspecification). ${ }^{23}$

The same logic underlying the extreme case of Bulgarian underlies less extreme cases, like the apparent differences between standard English and other variants of English (cf. (33)), or between English and Italian (cf. (32)).

For the difference between Standard English and non standard English varieties it is plausible to assume that the progressive periphrasis of the latter has less specified sets of conditions than the Standard English progressive periphrasis (for example, lacking the requirement that it involve an activity and a limited time span). As already noted, each aspectual category would need to be precisely defined semantically, but here we have to make do just with the logic of the matter.

As to the differences between the English and the Italian progressive periphrases (cf. (32) above) one can note with König (1995: 166) that in Modern English "this form has vastly expanded its range of possible contexts, meanings and uses beyond the core area found in earlier stages of English or in the use of analogous

23. For an attempt at characterizing semantically the common core of the Imperfect, the Progressive and the Habitual aspects (with the Imperfect defined by a general condition and two subconditions labeled Habitual and Progressive) see Cipria \& Roberts (2000: 323), and the discussion in $\$ 3.3$ of Portner (2011). Some languages have a general-purpose verb form which corresponds to the general condition of the Imperfect, while other languages have distinct verbal forms, one matching the general condition (Imperfect) and others matching the general conditions plus one of the two specific subconditions (hence a distinct habitual form and/or a distinct progressive form). 
forms in other languages". I interpret 'core area' here as referring to the (universal) aspectual notion 'Progressive' and the 'non-core area' to the extensions of the progressive periphrasis to express other aspectual notions (temporary interpretations of the Imperfective aspect, the Habitual aspect, etc.) (for similar remarks on the wide applicability of the English progressive periphrasis see Comrie 1976: 33; Dahl 1985: 90; Bybee et al. 1994: 135; Pustet et al. 2006: $\$ 3.1$ ).

The first two differences in (32) seem to depend on a peculiarity of the verb essere 'be' in Italian, i.e. its unavailability in the gerundive form of the progressive periphrasis, perhaps due to the exclusive stative character of essere in Italian (Comrie 1976: 33; Bortoluzzi 1992: 181). ${ }^{24}$ This appears to be confirmed by the possibility of using in (32a) a different (so-called "process") passive auxiliary venire 'come' (Lui stava venendo intervistato dalla polizia - Bortoluzzi 1992: 181; also see Bertinetto 2000: note 23) and, as noted in Bertinetto (2000), by using in (32b) the gerundivization of the verb fare 'do' plus the nominalization of the adjective: Lui sta facendo il cattivo). The other differences seem instead to be due to the mentioned extensions of the progressive periphrasis in English to cover other grammatical aspects. So, for example, (32c) appears to express a different aspectual category altogether; what Bertinetto et al. (2000) call Durative Progressive (distinguishing it from the Focalized Progressive of Italian and other languages), witness the fact that in Italian this aspect is rendered through a separate periphrasis 'stare $\mathrm{a}+\mathrm{V}_{\text {infinitive, }}$, compatible with the perfect and with a temporal measure phrase (not possible with the progressive periphrasis): Loro sono stati a pescare per 3 ore 'They have been fishing for three hours' vs. ${ }^{\star}$ Loro sono stati pescando per 3 ore. ${ }^{25}$

24. The form essendo, by itself, is possible in adverbial gerundive contexts: Essendo cattivo, Gianni avrebbe potuto benissimo rovinare tutto 'Being naughty, Gianni could very well have spoiled everything', vs. *Gianni sta essendo cattivo. 'Gianni is being naughty'.

25. Spanish appears to be like English in extending the progressive periphrasis to the same Durative Progressive aspectual category although a different, more specific, periphrasis involving llevar 'carry' $+\mathrm{V}_{\text {gerund }}$ is apparently also available (see $\$ 4.2 .6$ below). The distinct status of the two aspects may also be gathered by their different order with respect to deontic root modals. As observed in Bertinetto (2000: $\$ 3.1$ and note 13) the Spanish estar $+V_{\text {gerund }}$ progressive periphrasis can be embedded under such a modal in the Durative Progressive interpretation (just as its Italian counterpart stare $a+\mathrm{V}_{\text {infinitive }}$ can: Maria deve sempre stare a lamentarsi 'Maria must always be complaining about something'), while the Italian stare $+\mathrm{V}_{\text {gerund }}$ progressive cannot $\left({ }^{*}\right.$ Maria deve sempre stare lamentandosi). The latter can only be embedded under the higher epistemic and alethic modals (cf. Bertinetto 2000: note 13). Conversely, root deontic, but not the higher epistemic, modals can appear in the progressive periphrasis (Gianni sta dovendo ricredersi 'G. is being obliged to change his mind') suggesting that Progressive aspect is higher than deontic root modals. This is apparently confirmed by the following parallel contrast in Jambi Malay involving the progressive particle lagi and the root and epistemic/alethic modal biso 'can' (Yanti 2013: 251f): 
Concerning (32d-d') Smith (1997: 97) considers them to belong to a different aspect that marks a resultative viewpoint which continues for some time, though not permanently (see the contrast between The statue is standing in the middle of the hall and The statue stands in the middle of the hall). ${ }^{26}$

The related difference in (32e-e') seems to be due to the possibility in English (though not in Italian, where the simple present must be used) to extend the progressive periphrasis to cover the Imperfective aspect with temporary interpretation (vs. the simple present, I live in London, which conveys the interpretation of a more permanent imperfective state). Finally the difference in (32f-f') appears again due to the extension of the English progressive periphrasis (though not of the Italian one, where a different periphrasis is used: Lui è sempre che beve whisky) to Habitual aspect, in the presence of certain adverbials (what Kranich 2010: $\$ 3.3 .1$ terms "subjective progressive with ALWAYS").

For general discussion of differences between the English and Italian progressive constructions I refer to Marchand (1955), Bortoluzzi (1992), Bertinetto \& Delfitto (1996), and Bertinetto (2000).

Should this approach to the problem turn out to be feasible (and correct) there would be some confidence in postulating a specific Progressive aspectual category, as distinct from, say, an Imperfective, a Generic, or a Habitual one. The fact that

(i) a. oray-tu lagi biso datan

person-DEM.DIST PROG can come

'They are being permitted to come.'

*'It is possible that they are coming.'

b. oran-tu bisolagi datan

person-DEM.DIST can PROG come

'It is possible that they are coming.'

*'They are being permitted to come.'

All of this points to the overall order in (ii):

(ii) epistemic/alethic modals $>$ (Focalized) Progressive $>$ root modals $>$ Durative Progressive $>$ V stare + Vgerund stare $a+$ Vinfinitive

26. According to Smith (1997: 97) in English this aspect, which is limited to verbs of position and location, is rendered in Mandarin with the postverbal particle/suffix -zhe. This aspect may also correspond to the postverbal aspect particle yùu in Thai, which when co-occurring with the pre-verbal 'progressive' particle kamlay, indicates that "the event stays that way" for some time (Srioutai 2005: 213). Also see the "resultative progressive aspect" of Buol (Austronesian Zobel 2005: $\$ 5.2 .3$ ), formed by CVCV-reduplication, to express “ongoing resulting states" distinct from what the author terms "durative progressive aspect", which is expressed by adding a proclitic $d u=$ to the neutral tense form. Italian renders this case with the simple present or the imperfect rather than with the progressive periphrasis (La statua giace/giaceva sul pavimento 'the statue is/was lying on the floor' vs. ${ }^{*}$ La statua sta/stava giacendo sul pavimento 'the statue is/ was lying on the floor'). 
languages differ as to the class of verbs which their progressive morphology applies to (or in some other way) may then be a purely morphological effect. The progressive periphrasis in Indian English can be taken to be the exponent not only of Progressive aspect but also of other aspects, and the same holds true of the Bulgarian present as opposed to the English present.

Perhaps it would be more correct to think that the Bulgarian present (or past imperfect) morphology in contexts compatible with a progressive interpretation actually co-occurs with a silent Progressive aspect head (see (40b)), while Italian would optionally overtly combine the present morphology in the specifier of a silent Present head with the overt progressive morphology in the specifier of a silent Progressive aspect head (see (40a)):

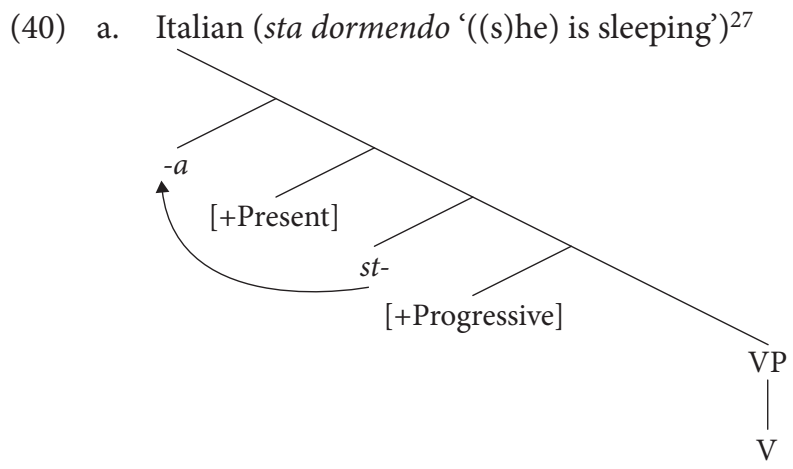

dorme-ndo

b. Bulgarian (spi '((s)he) is sleeping')

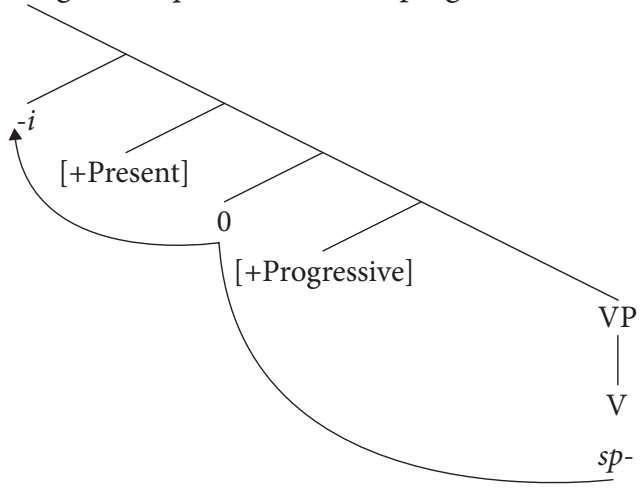

This conjecture may find some support from a comparable difference between the English perfect on one side and the Indonesian and (some) Vicentino dialect

27. Stare may be the incorporation of a preposition, $a$ 'at', the exponent of Progressive aspect in the specifier of a silent head bearing the feature Progressive, to an auxiliary (essere 'be'). 
perfects on the other. One of the interpretations of the English perfect is the socalled Experiential Perfect interpretation (Bill has been to America - Comrie 1976: $\$ 3.1 .2$; Bhatt \& Pancheva 2005b: $\$ 3.1$ ). This interpretation is reported to be rendered in Indonesian with the ordinary perfect particle sudah followed by the aspectual particle pernah, which Grangé (2013:65) terms "semelfactive perfect + experiential modality" ('has already had the experience of'). See (41):

(41) Saya sudah pernah ke-tipu.

(Grangé 2013: 65)

1SG PFCT SEMF DETR-lie

'I have had the experience of being cheated.'

In some North-East Italian dialects of the province of Vicenza the same interpretation appears to be available (in root contexts) with the so called 'surcomposé forms, where an additional perfect auxiliary is added to the ordinary perfect auxiliary. ${ }^{28}$ See (42a) and (42b):

a. Go bio visto il papa

I.have had seen the pope

(Vicentino of Cereda - Poletto 1993: 294, 2009: 35)

'I've seen the pope/It happened to me to see the pope'

b. L'este mai abù fata sta roba?

It.have-you ever had done this thing?

'Has it ever happened to you to do something like that?'

(dialect of Canazei, Rhaetoromance, Poletto 2009: 35)

These languages thus make it plausible to assume (at least) two separate Perfect aspect projections, the lower one of which we may call Experiential Perfect. In Indonesian this projection is lexicalized by the particle pernah, which co-occurs with the ordinary perfect particle sudah while in Vicentino it is lexicalized by a second 'perfect' auxiliary (cf. Poletto 1993).

28. As to the French "surcomposé" forms (which in the Standard are only found in subordinate contexts - Dauzat 1954: 260f), they may instantiate, perhaps in addition to the Experiential Perfect, other types of Perfects (Saussure \& Sthioul 2012). The literature (on English) mentions, for example, the 'Hot news Perfect', the 'Resultative Perfect', and the 'Recent Past Perfect' (see Bhatt \& Pancheva 2005b and references cited there). For other "surcomposé" forms in other languages, which, again, may well cover different types of Perfects, see Amman (2007), Poletto (2009) and references cited there. Saussure \& Sthioul (2012: 606 note 2) report the existence of "surcomposé" forms with an apparently 'experiential' flavour even in (some varieties of) English:

(i) a. You are one of the strongest people I have had known

b. I have had seen senior runners who have taken tai chi or yoga and over about six months increased their flexibility ...

c. I've had gone through that experience before.

d. What is the most unusual thing you have had eaten from a barbeque? 
(43)

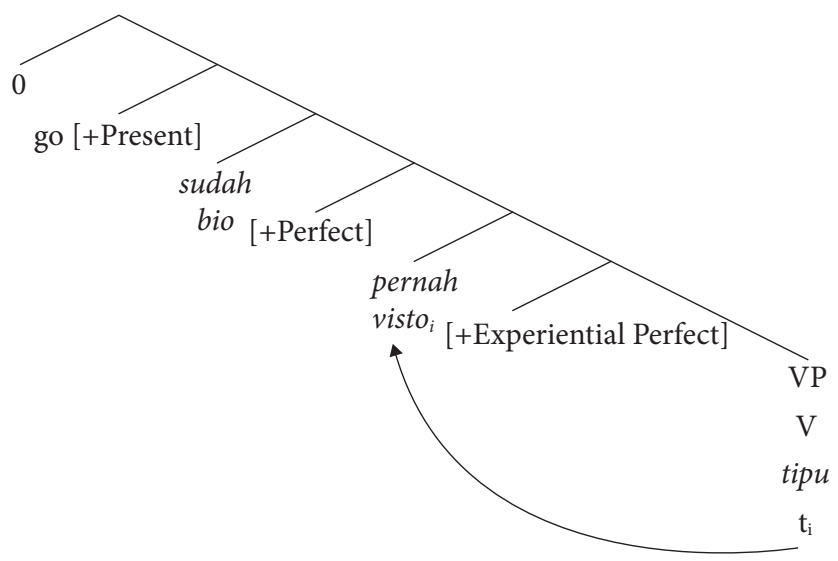

English would then differ from Indonesian and Vicentino in simply having a silent Experiential Perfect head with no overt morphology in its specifier (much as I suggested is the case for the Progressive projection in Bulgarian).

In the next section I briefly consider how the Progressive aspectual category comes to be expressed in different languages (abstracting away from possible extensions of the same form to other aspectual categories). ${ }^{29}$ The goal is to see whether one can reconstruct a single, more complex, phrasal structure in specifier position (with different unpronounced parts) that may allow one to dispense with a holistic category/feature "Progressive", or whether one such holistic feature should be assumed to be present in the silent head in whose specifier is located the overt progressive morphology, if any (as I have implicitly assumed so far).

\subsection{The cross-linguistic expression of Progressive aspect}

\subsubsection{Locative source progressives}

As many authors have observed, Progressive aspect is very often rendered through some form of locative expression (Bybee et al. 1994: $\$ 5.2$, and references cited there; Nurse 2008; ${ }^{30}$ Kayne 2016: $\$ 5$; Williams 2016, among others). These locative expressions can take different forms, some of which are reviewed from $₫$ 4.2.1.1 to

29. That is to say, I will consider as 'progressive' morphology those forms that seem to cover the basic properties of the Progressive aspectual category mentioned in the text below (30) and (31) (or are so presented in the descriptive literature) independently of the possibility that the same forms cover additional aspectual categories.

30. "Progressives deriving from locatives are the commonest type across Bantu" (p. 139) - the second commonest being 'be with + Vinf'; see $\$ 4.2 .9$. Less common strategies in Bantu are those involving reduplication $(\$ 4.2 .16)$, tone $(\$ 4.2 .17)$ and focus (cf. $\$ 4.2 .18$ ). 
$\$ 4.2 .1 .8$. Progressive aspect can however also be expressed by some non locative periphrases, which are reviewed from $₫ 4.2 .2$ to $\$ 4.2 .20$.

4.2.1.1 'Locative preposition + a nominalized form of $V$ ' progressives.

Among the languages that render Progressive aspect with a locative preposition $+\mathrm{a}$ nominalized form of the verb are, among others, Danish ('be at $+\mathrm{V}_{\text {infinitive }}$ '), German and Dutch ('be at the $\mathrm{V}_{\text {nominal }}$ '), Godié, Tyurama, Maninka, Burmese, Thai ('be at') (Heine \& Kuteva 2002: 97ff), Irish ('at' + verbal noun ) (Blansitt 1975: 19) Chinese ('at $+\mathrm{V}$ '). ${ }^{31}$

4.2.1.2 'Stay $+V_{\text {gerund }}$ 'progressives.

Italian (and other Romance languages) ${ }^{32}$
Quando sono entrato, stava mangiando
when I.am entered, he.stayed imperf $_{\text {eating }}$
'When I entered, he was eating'

31. Also see Bybee et al. (1994: 128). Possible covert locative progressive forms can be the Icelandic 'be' $+\mathrm{V}_{\text {infinitive }}$ periphrasis: Hún var/er/verður að mála 'She was/is/will be painting' Sigurðsson (2004: 244); Sigurðsson \& Maling (2012:375), and the form reported in Pusch (2003: $\$ 4$ ) in the French of the island of Saint Barthélemy: être qui + finite verb:

(i) Maman est qui m'arprend à faire $\mathrm{d}(\mathrm{e})$ la tresse mother is that me teaches to do the straw 'Mother is teaching me to plait (straw)'

or the 'be' $+q \ddot{e}$ ('that') + finite verb of certain Arberesh (Albanian) dialects of Italy (Bertinetto et al. 2000: note 4). This form is reminiscent of pseudo-relative forms like Elle est là qui pleure comme une Madeleine (Kayne 1975: 126), which alternate with a present participle: Elle est là pleurant comme une Madeleine. The form may possibly have a silent locative adverb (which is optionally overt in the parallel Ligurian progressive form mentioned in Forner (1997: 251): A le (li) $k$ a sente 'lit. $\mathrm{Cl}$ she is (there) that she hears = she is hearing'). Perhaps the Tepehuan progressive periphrasis 'be $+V_{\text {infinitive }}$ ' (Watters 1998: $\$ 2.4 .1 .4$ ) could be similarly analyzed with a silent locative preposition.

The combination 'be (away) + Vinfinitive' in other languages expresses a different aspect; the so-called 'absentive aspect' (de Groot 2000), which expresses the fact that someone is away from some specific place doing something. This is the case with the Italian periphrasis essere (via) $a+\mathrm{V}_{\text {infinitive }}$ 'to be (away) at V' (Gianni è (via) a pescare/lavorare 'Gianni is away/off fishing/ at work' and the Catalan one En Pep es/està a dinar 'Pep is off eating' vs. En Pep està dinant 'Pep is eating' (http://www.ub.edu/diccionarilinguistica/content/absentive).

32. Although, as noted, Romance languages differ among each other even if using 'stay' in their periphrasis. See for example fn. 25.

In North Indian languages (Hindi, Urdu, and Punjabi), the progressive aspect is also expressed with the perfect participle of the verb 'stay'/'remain' (Comrie 1976: 102). Also see the 'remain’ suffix of the Sino-Tibetan language Kwopa Newar (Regmi 2012: §8.3). 


\subsubsection{3 'Stand'/'sit'/lie'/'hang' progressives.}

Progressive aspect is expressed in several languages (Diola-Fogny, Mamvu, Nobiin, Ngambay-Moundou - Heine \& Kuteva 2002: 276) with postural/positional verbs followed by the lexical verb. See for Example (45): ${ }^{33}$

(45) i-lako fu-ri

(Diola-Fogny - Heine \& Kuteva 2002: 276)

1sG-sit INF-eat

'I was eating'

\subsubsection{4 'Live + V'progressives.}

A number of languages express Progressive aspect with the verb 'live', used as an auxiliary (plausibly with a locative interpretation). For example in Aguaruna (a Jivaroan language of Peru) "progressive is typically expressed with constructions involving the simultaneous subordinator $-k u$ and the auxiliary verb puhu 'live"' (Overall 2007: $\$ 8.3 .2$ ), as in (46):

(46) maa-ku-nu puha-ha-i

(Overall 2007: 333)

bathe.IMPFV-SIM-1SG:Ss live.IMPFV-1SG-DECL

'I am bathing'

Punjabi, among other Indo-Aryan languages, also uses 'live' as an auxiliary verb in progressive periphrases: ${ }^{34}$
mãi so ríaa ãã/sãã
I sleep PROG.Ms. am/was
'I am/was sleeping'
*I am/was in the state of sleeping'

(Bhatia 1993: 254)

Also see the 'live' and 'live for' progressives of the Cushitic language Kulisi Agaw (Zelealem 2012: 25) and Ghanian Pidgin English (Winford 2012: 445).

\subsubsection{5 'Inside/middle/midst $+V$ 'progressives.}

Another way to encode the progressive is via the locative expressions "inside/in the middle of". See for example the cases of Daai Chin (48a), where the progressive

33. When such positional verbs are used as light predicates in the progressive construction, selectional restrictions still obtain. Thus, for example, in Mebengokre "an ongoing combing activity [or rain falling] combines naturally with progressive dja 'be standing', an ongoing reading activity triggers auxiliary $n h \tilde{y}$ 'be sitting', and an ongoing sleeping activity is better described via auxiliary nõ 'be lying”' (Arregui et al. 2014: 348).

34. "The progressive aspect is expressed by means of rái [rce'], which is homophonous with the stem of the verb re' $\mathrm{Naa}$ 'to live.' [..] The progressive aspect is used with active verbs alone." (Bhatia 1993: 254). 
prefix k'um means 'inside', and those of Mualang, Kadorih and Hoava in (48b-d), where the progressive particles mean 'midst/middle':

(48) a. Je ta do:ng k'um=kti

Hare FOC run PROG=NON-FUT

(Daai Chin - Sino-Tibetan - So-Hartmann 2009: 262)

'As for the hare, he is [in the middle of] running

b. Ia tengah $\mathrm{N}$-pakay

(Mualang - Malayic - Tjia 2007: 195)

3sG middle ACT-eat

'He is /was eating'

c. puun sohit nanai [..], ahku beteng=ku bagawi

base evening a.moment.ago 1sG midst=1sG work

(Kadorih - Malayo-Polynesian - Inagaki 2013: 107)

'At the beginning of this evening, I was working,'

d. Korapa hao raro se Amina (Hoava-Oceanic-Davis 2003: $\$$ 5.4.2) ${ }^{35}$ middle wash pot ART Amina

'Amina is washing pots.' (cf. korapa rane 'middle (of) day)

4.2.1.6 'Be near to $+V_{\text {infinitive }}$ 'progressives.

The Piedmontese progressive periphrasis esse appress $a+V_{\text {infinitive }}$ 'to be near to $\mathrm{V}_{\text {infinitive }}$ ' Cerruti (2009: 141) is another way to express the Progressive aspect through a locative expression.

4.2.1.7 'Be present $+V$ ' progressives.

In Ternate Malay yet another locative expression is used: 'be present.' "When ada 'be present' is combined with a construction expressing an action, process, or a state, the result is a construction within which ada expresses a progressive meaning, indicating that an action, process, or a state (of affairs) is progressively taking place at a certain moment in time and will continue for some time." (Litamahuputty 2012: \$7.4.2.1) (for Papuan Malay Kluge 2017: 262f renders ada with the verb 'exist'):

(49) mangkali ada balajar bela diri. (Litamahuputty 2012: 226) maybe PROG learn defend self 'Maybe she's learning how to defend herself.'

35. Another way to express progressive aspect in Hoava is via reduplication (which can combine with korapa):

(i) Korapa igu=igunu ria koburu

(Davis 2003: 145)

Prog RED-play ART.PL child

'The children are playing.' 
4.2.1.8 'Be behind $+V_{\text {infinitive }}$ 'progressives ${ }^{36}$

(50) a. El ze drio magnar(e)(Veneto, several dialects) (cf. Poletto 2008: §3.1) he is behind eat infinitive $_{\text {. }}$

'He is eating'

b. a son dre far

(Emilia-Romagna - Cordin 1997: 97)

I am behind do $_{\text {infinitive }}$

'I am doing'

c. i sun da’re a 'skrivi

I am behind at write infinitive $_{\text {. }}$

(Piemonte - Bertocci \& Rossi 2011: 53; also see Cerruti 2011: 82)

'I am writing'

4.2.2 'Be after/before $+V$ 'progressives

In 16th/17th c. French être après à 'to be after at' $+\mathrm{V}_{\text {infinitive }}{ }^{37}$ was used as a progressive periphrasis. See Pusch $(2003: \S 3)$, where it is said that it is "très vivante aussi bien en français québécois qu'en français acadien. Dans l'acadien parlé en Louisiane, c'est la seule expression de l'aspect progressif courante dans l'usage actuel." ${ }^{38}$ Although it was originally locative in character, in 16th c. French it was predominantly temporal (Fagard 2003: 241).

(51) a. Y était après chanter quand j'ai ouvert la porte 'He was singing when I opened the door'

b. Là il est après faire de la charpente

(québécois)

'There he is doing some carpentry work'

(acadien louisianais)

36. The same progressive periphrasis is reported to be used in the Lombard dialect of Pavia by Bertinetto (2000: note 23). Although apparently locative, this periphrasis may be related to the 'be busy/engaged/occupied with' periphrasis (cf. $\$ 4.2 .7$ ) since in Venetian el ze sta drio ai nevodi 'lit. he is stayed behind the grandchildren' means 'he attended/occupied himself with his grandchildren'.

37. See, for ex., (i) (Descartes, Lettre au P. Marsenne 1630 - Squartini 1998: 123)

(i) Je vous dirai que je suis maintenant après à demesler le chaos pour en faire sortir de la lumière.

'I will tell you that I am now unravelling the chaos in order to get light from it.'

38. As Pusch (2003: $\$ 3)$ notes, this periphrasis is considered by creolists to be at the basis of the preverbal progressive particle ap/ape, characteristic of the French-based creole languages of Luisiana and Haiti. The progressive periphrasis être après $+\mathrm{V}_{\text {infinitive }}$ is also documented in Provence, in the Franco-Provençal area, and in the middle and low Loire Valley (Squartini 1998: 122). 
Also see Squartini (1998: 122), and Vinet (1998: 189) on Quebec French Quand chus [= je suis] arrivé, elle était-tu pas après manger la tarte 'When I arrived, she was eating the cake. ${ }^{39}$

In the Oceanic language Tinrin progressive aspect is instead expressed through a particle, $n r a ̂$, which "is homophonous with the posthead verbal modifier nrâ 'before” (Osumi 1995: 177).

\subsection{3 'During/while $+V$ 'progressives}

"The word lolotoga 'during, while' can be employed to describe an ongoing, incomplete, progressive aspect" (Livingston 2016: 109)

(52) ne'e lolotoga moe ia Kusitino (East Uvean - Livingston 2016: 109) PST PROG sleep HUM Kusitino

'Kusitino was sleeping'

4.2.4 'Be in the course of $+V_{\text {infinitive }}$ 'progressives ${ }^{40}$
a. j'était en train de manger ${ }^{41}$
I was in course of eat infinitive 'I was eating'
b. Să fi în curs de a lucra
(Romanian) mood particle be in the course of work $_{\text {infinitive }}$ 'to be working'

39. Bolinger (1971:246) mentions the existence of an English dialect which uses after in the progressive periphrasis (He is after telling her). In Hiberno-English after V-ing instead expresses the Perfect (or possibly the Retrospective) aspect (see (ia) from Berizzi \& Rossi 2010: 19), which may be a calque from Irish and Welsh 'after' + a nominalized form of the verb, which expresses the Perfect. See (ib-c), from Ronan (2012: 228).

(i) a. She is after breaking the window

'She has just broken the window.'

b. Tá mé tréis canadh.

(Modern Irish)

c. Dw i wedi canu. (Modern Welsh)

Be.PRES. I after singing.vN

'I have sung'

40. In English this periphrasis is possible (roughly with a progressive reading) with a gerund: They are in the course of becoming ungrammatical.

41. Etre en train de (etymologically from traîner 'to drag', whose pejorative overtones may be at the basis of the negative connotations of certain of its uses - cf. fn.21) has taken up the more metaphorical meanings of "processus en course" (Lachaux 2005: 121), "deroulement d'une action en cours" (Do-Hurinville 2007: 33). 


\subsection{5 'Be on the way' progressives ${ }^{42}$}

(54) a. Le masnà a sun an camin c'a giøgu ant la curt The children cl are on the way that $\mathrm{cl}$ play in the courtyard

(Piedmontese - Romance - Bertocci \& Rossi 2011: 54)

'The children are playing in the courtyard'

b. Det vara på väg att $+V_{\text {infinitive }}$

it was on way to $V_{\text {infinitive }}$

(Swedish: less productive periphrasis - Blensenius 2015: 35) 'it was V-ing'

4.2.6 'Carry (on)' progressives

(55) Han dreiv og las (Nynorsk - Germanic - Ebert 2000: 635)

he carried_on and read

'He was reading'

(56) cuantos años llevas estudiando euskera how.many years carry.PRs.2sG study.gerundive Basque

$\left(\right.$ Spanish - Jendraschek 2006: 157) ${ }^{43}$

'How many years have you been learning Basque?'

(57) zenbat urte daramatza-zu Euskara ikas-ten?

how.may year carry.PRS3PL.ABS-2sG.ERG Basque learn-IMPF

(Basque - Jendraschek 2006: 157)

'How many years have you been learning Basque?'

4.2.7 'To be occupied/engaged in/busy with' $+V$ ' progressives ${ }^{44}$

Afrikaans (Germanic - Duquesne 2013) ${ }^{45}$

(58) Globalisering is ook hier besig om sy tol te eis

Globalisation is also here busy INF.C his toll to demand

"Globalisation is also taking its toll here."

42. Also see the progressive prefix si்- of the Kwa language Ikposso Uwi, which "provient du verbe $s \dot{\varepsilon}$ 'marcher”' (Soubrier 2013: \$2.9.9).

43. As observed in fn.25, in Spanish (as well as in Basque - cf. (57)) this periphrasis can possibly encode a related aspect; what Bertinetto et al. (2000) call Durative Progressive.

44. Also see the Faroese progressive periphrasis er fáast við at 'to be busy with to V' (Ebert 2000: 635), the "occupative" aspect of the Nilo-Saharan language Ik (Schrock 2014: \$ 9.5.3), and the progressive particle leki of Pattani (Sino-Tibetan), which derives from 'to be engaged in' (Sharma 1982: 173).

45. Duquesne (2013) states that this is the more frequently used progressive periphrasis in Afrikaans. This was confirmed to me by Theresa Biberauer (p.c.), who mentioned that it has 
Javanese (Malayo-Polynesian - Vander Klok \& Déchaine 2014: 556) ${ }^{46}$

(59) Dewi ewoh numpak sepeda montor

Dewi busy Av.ride bike motor

'Dewi is riding a motorbike.'

Khmer (Austroasiatic - Haiman 2011: 267) ${ }^{47}$

(60) pdej niang kampung pralaeng lee:ng cia muaj plau:ng husband missy Prog play play with fire 'Her husband is playing with fire'

Basque (Laka 2006: 173f). Cf. (61a) with (61b):
a. emakume-a ogi-a ja-te-n ari da woman-DET(ABS) bread-DET eat-NOM-LOC engaged is 'The woman is (engaged in) eating the bread'
b. emakume-a-k ogi-a ja-te-n du woman-DET-ERG bread-DET eat-NOM-LOC has 'The woman eats (the) bread'

If Laka (2006) is right in analyzing the Basque progressive periphrasis with ari ('to be engaged in') as a biclausal unaccusative structure, with ari taking a PP with a nominalized clause complement in order to account for the Absolutive rather than Ergative Case assignment to the subject (but see Hualde \& Ortiz de Urbina 1987 for the proposal of a restructuring from a biclausal to a monoclausal one), the entire ari + PP could perhaps be in the specifier of a silent (Progressive) head. But also see Laka (2006: $\$ 4.1$ ) on eastern varieties of Basque that give evidence for a monoclausal analysis of the ari periphrasis. ${ }^{48}$

even influenced South African English, where it's entirely natural to say He is busy dying/not doing a thing/sleeping. The same periphrasis is a secondary strategy for coding Progressive aspect in Dutch (cf. Donaldson 1981: 165).

46. Vander Klok \& Déchaine (2014: 556) report that "progressive aspect ewoh 'busy' is compatible with events such as numpak 'ride', but not with states such as eling 'remember'. Infelicity with ewoh 'busy' is also seen with state predicates ngerti 'understand', seneng 'like', doyan 'like [food]', percoyo 'believe', lali 'forget', tresno 'love"..

47. kampung (tae): "be engaged or busy in”/PROG (Haiman 2011: Chapter 8, \$ 2.2.6).

48. A similar biclausal analysis of the progressive periphrasis in the Mayan language Chuj (to account for the pattern of Absolutive/Ergative Case assignment) is proposed in Carolan \& Coon (2015) and Coon \& Carolan (2015). Jessica Coon however tells me (p.c.) that the structure is not a structure involving two full clauses. 


\subsection{8 'Hold' progressives}

In a number of languages Progressive aspect is rendered with a periphrasis containing the verb 'hold'. See (62) through (66): ${ }^{49}$

Swedish: håller på (med) att $+\mathrm{V}_{\text {infinitive }}$ (Blensenius 2015; Christer Platzack p.c.):

(62) Det höll på att regna i går

(Blensenius 2015: 22)

(lit. it held on to rain yesterday)

'it was raining yesterday'

Yiddish (Germanic - Ebert 2000: 632f)

(63) Ikh halt in shraybn

I hold in write ${ }_{\text {infinitive }}$

'I am writing'

Likpe (Kwa - Ameka 2002: $\$ 4.0)^{50}$

(64) ว-sวmi lé bo-ni CM-rain hold CM-fall ${ }_{\text {verbal noun }}$

'Lit. Rain holds falling'; i.e., 'it is raining.'

(65) Waata dialect of Oromo

(Afro-Asiatic - Kuteva 1998: 305):

utaal-ca harka k'aw-a

run-NOMIN hand hold-3M.SG.PRES

'He is running'

(66) Abruzzo-Molise dialects (Romance), Italy

a. Təném a mmagná

(Rohlfs 1969: 133)

we.hold to eat infinitive $_{\text {. }}$

'We are eating'

b. té ppjjove

(Ledgeway 2016: 266)

it holds rain infinitive

'it is raining'

49. Also see the case of Tamil, which "utilizes a combination of two auxiliary verbs, $k o$ l 'hold' (or koo in spoken Tamil) and iru 'be', which appear together as - kitt-iru for expressing progressive aspect" (Boutwell 2000: 86). It is also one of the progressive periphrases of Norwegian Bokmål (je holder på (med) å skrive et brev 'I am writing a letter' - Ebert 2000: 634).

50. The main verb "is nominalized by prefixing the class marker for verbal nouns to the verb root" (p. 97). If the verb is transitive the object precedes the verbal noun:

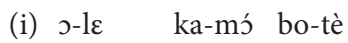

3sg-hold CM-rice cM-sell

'S/he is selling rice' 


\subsection{9 'Be with' progressives}

This progressive periphrasis is found in a number of African languages (e.g. Lunda, Umbundu, Ngbaka, Birom):

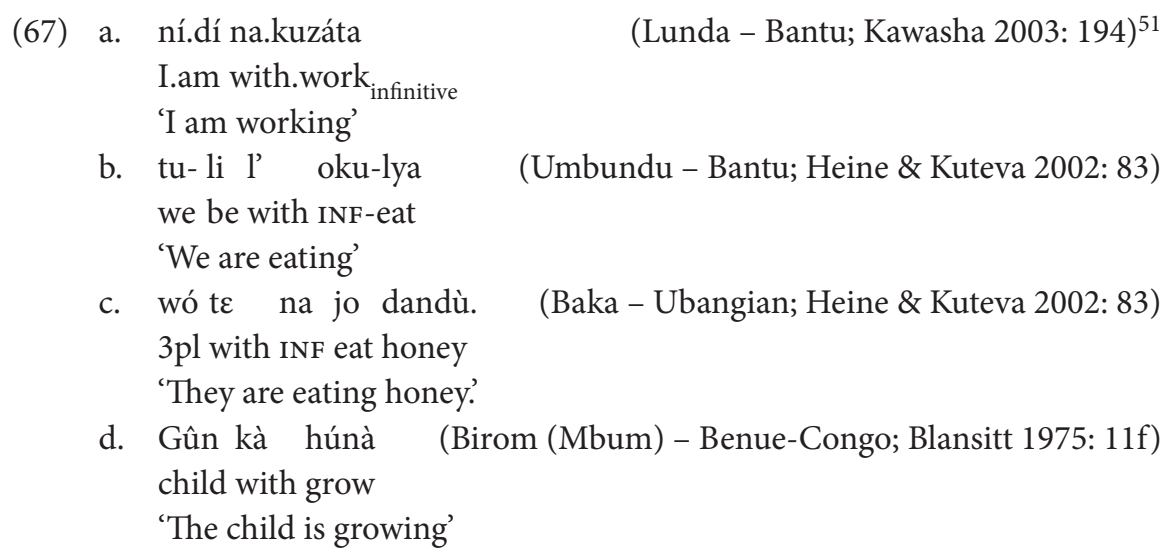

\subsubsection{0 'Have' progressives}

In other languages the progressive periphrasis involves the auxiliary verb 'have'. See (68):
a. Man dār-am
dars mi-khon-am
(Persian - Vafaeian 2012: 13)
I have.PRS-1sG lesson DUR-read.PRS-1SG
'I am studying'
b. Man maktab-I fav-ak ast
I school-LOC go-INF have

(Yaghnobi (Indo-Iranian) - Vafaeian 2012: 18)

'I am going to school'

\subsubsection{1 'Do' progressives}

Progressive aspect can apparently also be expressed by the functional verb 'do' taking the lexical verb as its complement. Jäger (2006: \$6.2.2.2) reports this to be the case in a number of Niger-Congo (Kpelle, Ngindo), Tibeto-Burman (Tangkhul and Chantyal), Mayan (Ixil, Awakatek, and Cunén Kiche), Nilo-Saharan (Bongo), and English based Creole languages (Bajan and Gullah). See for example the case he reports from Gullah in (69): ${ }^{52}$

51. "The present progressive is formed periphrastically by means of the copular di 'be' or túmbi 'be' as an auxiliary verb followed by na- 'and, with' plus the main verb in the infinitive form." (p. 194)

52. A verb glossed 'do' is also used as auxiliary in progressive constructions in Southern Barasano (Tucanoan - Blansitt 1975: 28) and Nias (Malayo-Polynesian - Brown 2001: § 10.3.22.1), and it 
(69) dem duh eat and duh laugh 3PL do eat and do laugh 'They were eating and laughing'

'Do' is also used to mark progressive aspect in the Papuan language Bunaq of Timor (Schapper 2009: \$14.2.3.2):

(70) Baqi heser on,... DEM dead Do

(Gullah - Jäger 2006: §6.2.2.2)

'(When) she was doing dying,...' i.e 'She was in the process of dying,...'

Kortmann (2004) reports that do was also employed as a progressive marker in 18th/19th century English dialects of the Southwest of England. See (71):

(71) Do rain, don't it?

'It's raining, isn't it?'

(Kortmann 2004: 246)

\subsubsection{2 'Now' progressives}

One of the ways in which progressive aspect is marked in the Philippine language Bantik (alongside reduplication) is "by using kahagasa, which means 'now' if used alone, plus the linker $n u$ ” (Utsumi 2013: 221):

(72) toumata kahagasa nu ma-narimu? barei people now LK AV.NPST-make house 'People are building a house'

In the Fehan dialect of Tetun (Malayo-Polynesian) the auxiliary ho' $i$ 'currently' indicates progressive aspect (van Klinken 1999: \$ 10.3.2):

(73) M-aré. Manu oan n-o’i kokorék.

2s-see. bird small 3s-currently crow

Look. The cock (lit. 'small bird') is crowing.

Also see the case of German gerade (jetzt/JETZT) 'right (now)' (Er liest gerade (jetzt) das Buch 'He is reading the book'), and of the Panoan language Chacobo cited in Bybee et al. (1994: 140). On this strategy also see Blansitt (1975: 6f).

appears to be at the basis of the Progressive form in Kakua (Makú-Puinave) (Bolaños Quiñonez 2016: \$10.2.2). Also see Heine \& Kuteva (2002: 118f). 


\subsubsection{3 'Still, yet' progressives}

In the Malayo-Polynesian language Madurese ' $G i$ ' 'still, yet' is an adverbial that indicates that some state of affairs still obtains or is in progress. With active verbs, $g i$ ' + verb has a progressive interpretation, as in [(74)]" (Davies 2010: 268): $:^{53}$

(74) Tang ana' gi' a-sapo kamar-ra. my child yet AV-sweep room-DEF

'My child is sweeping his room.'

\subsubsection{Progressive particles and affixes with no transparent meaning}

In several languages the morphemes that convey progressive aspect are not (or are no longer) semantically transparent, as the progressive aspect particle sedang of Indonesian (75a), ${ }^{54}$ the progressive particle kambuy (-dir) of the Mon-Khmer language Stieng (75b) (Bon 2014: $\$ 7.2 .2 .1),{ }^{55}$ the progressive auxiliary/suffix /- ${ }^{3}$ afe-/ of the Madang Papuan language Tauya (75c), ${ }^{56}$ the progressive prefix $i$ - of the Alor-Pantar Papuan language Western Pantar (75d) (Holton 2014: $\$ 7.2 .2$ ), or the na- prefix of the Sino-Tibetan (Qiangic) language rGyalrong (Prins 2011: 401ff) (75e) (or the $m o$ - prefix of the Oceanic language Unua (Pearce 2015: 27)): ${ }^{57}$

(75) a. dia sedang makan

(Pustet et al. 2006: \$3.4)

3SG PROG eat

"He/she is eating"

53. An apparently identical case is that of the Tibeto-Burman language Qiang, where " $t]$ he prefix [tçe- tçi- tça- tço-] 'still,yet' is used to express present progressive actions” (LaPolla 2003: 582). Similarly, in the Oceanic language Gabadi the adverb 'still' is used to signal a continuous/progressive interpretation (cf. Oa \& Paul 2013: \$ 5.3). Cf. Timberlake’s (2007: 287) remark that “[o] ften the progressive implies that the activity is going on 'still' (longer than expected)".

54. “The diachronic source of the element sedang is unknown" (Pustet et al. 2006: 202).

55. Bon (2014: 392) states that the Stieng progressive particle, kambuy (-dir), utilized only with active verbs, "is derived from the Khmer morpheme kampun ( $t a \varepsilon)$, which has the same function and whose lexical origin is 'to be busy, occupied' (Haiman 2011: 267) [see $\$ 4.2 .7$ above]. The form kambuy is nonetheless not attested as a full verb in the corpus and the speakers asked could not give it a lexical sense." (Bon 2014: 393) [our translation].

56. "[T]here are no attested verb roots with which the progressive may be cognate, and the progressive itself occurs only as a suffixed auxiliary” (MacDonald 1985: 356).

57. Raji (SOV, Tibeto-Burman, Himalayan - Rastogi 2012: $\$ 4.3 .1 .1$ ) has one progressive postverbal particle, $h \tilde{a}$, for 1st and 3rd person and an altogether different particle, fya, for 2nd person. Neither of the two is reported as transparent in meaning. 
b. sow kəmbun dir roək nhiəm

(Bon 2014: 392)

chien PROG chercher maittre [dog prog look for master]

'Le chien est en train de chercher (son) maître' [the dog is looking for its master]

c. sawi ni-'`afe-a-'?a

(MacDonald 1985: 355)

banana eat-PROG-3SG.-IND

'He's eating bananas'

d. n-iu ang me i-golang

(Holton 2014: $\$ 7.2 .2$ )

1sG.POss-mother market LOC PROG-return

'My mother is returning from the market.'

e. pafur lhamo tənge ki na-trop-w

(Prins 2011: 402)

yesterday lHa.mo clothes IDEF PST PROG-sew-3s

'Yesterday lHa-mo was sewing a piece of clothing.'

\subsubsection{5 'Subject clitic' progressives}

The Romance dialect of the island of Pantelleria (between Sicily and Tunisia) shows yet another strategy for encoding progressive aspect: the insertion of a subject clitic matching in person, number and gender the preceding subject (see Loporcaro 2012 and Franco 2013):

(76) a. '1d:z-1 'part-unu

(Loporcaro 2012: §1)

3-PL leave.pres-3PL

'They leave' or 'They are leaving' (unmarked for aspectual values)

b. '1d:z-1 d: $z^{-1} \quad$ 'part-unu

3-PL CL3-PL leave.pres-3PL

'They are leaving' (progressive aspect)

One may wonder whether this construction is related to the progressive construction of the Iranian language Dimili, which "consists of a clitic that is added to the subject of the verb while the verb itself remains unchanged. The clitic agrees with the subject in person, number and gender." (Todd 1985: $\$ 3.2 .2 .1$ ): ${ }^{58}$

(77) ti-yê 'ereva ramen-ê

(Todd 1985: 102)

you-PROG car drive-2sG

'You (masc.) are driving the car'

58. Loporcaro (2012: $\$ 5.2$ ) discusses other languages where aspect involves pronominal forms but shows that they either mark aspects distinct from the Progressive or if they do mark Progressive aspect they are quite distinct from the pronominal marking of the Pantiscu dialect. 


\subsubsection{6 'Reduplication' progressives}

Morphological reduplication of (different segments of) the verb root is also a widespread means, it seems, to render the progressive. For example, "reduplication is regularly used to express progressive aspect" in Oceanic languages (Hyslop 2001: 341). See (78) from Mokilese, where it is expressed by "reduplicating the first syllable (usually CVC) of the verb." (Harrison 1976: 220):

(78) a. wadek 'to read' wadwadek 'to be reading'

b. piload 'to pick breadfruit' pilpiload 'to be picking breadfruit'

Reduplication is also found expressing progressive aspect in other language families, e.g. in Bantu languages. For example, in Kom (Chia 1976: 112ff) the present progressive contrasts with the generic/habitual present in involving full reduplication of the verb. See (79a) vs. (79b):
a. Daniel nùn gúfu-gūfú
Daniel PREs drive-drive
'Daniel is driving'
b. Daniel nùn gúf-à
Daniel PRES drive
'Daniel drives'

Also see the case of the Niger-Congo languages Kanyoka (Nurse 2008: 152) and Tima (Alamin 2012: 87).

Progressive aspect is also marked by reduplication in the Formosan branch of Austronesian. See Lha'alua (Pan 2012: 196f), where it is expressed by CVreduplication of the verb stem, but also Paiwan, Bunun, Rukai, and Puyuma (Zeitoun et al. 1996:46), ${ }^{59}$ in the Philippine language Bontok (Thurgood 1997: 137), in the Arawakan language Palikur (Derbyshire 1986: 502), in the SinoTibetan language Sunwar (Borchers 2008: \$6.7), and in the Amerindian Salish language Skwxwú7mesh (Bar-El 2005: Chapter 5, §3.1). ${ }^{60}$

\subsubsection{Tone marked progressives}

In a number of African languages progressive aspect is expressed through a tonal alternation. In the Grassfield Bantu language Bafut "the progressive aspect occurs with dynamic (non-stative) verbs. The progressive marker in these verbs is the high tone" (Ambe 1989: $\$ 4.3 .1 .3$; also see Tamanji 2009: 129). The same holds of another

59. While in Puyuma reduplication denotes just the progressive, in the others, it may additionally express iterative or habitual aspects.

6o. In other languages, reduplication expresses aspects different from the Progressive or entirely different grammatical notions. 
Grassfield Bantu language, Babanki (see Akumbu 2015: $\$ 4$ and $\$ 5$ ), and in the Edoid language Bini (cf. Blansitt 1975: 9). In the Ekpheli dialect of the Edoid language Etsako "only tonal alternations in the pronominal prefix, the verb stem and the noun object reveal the tense and aspect. [In the present progressive] verb tone affects the initial tone of the noun object"' (Elimelech 1978: 85): 'odóyèdê 'he is buying a banana.' In Dholuo (Nilo-Saharan) progressive aspect is marked by a "high tone that runs through the verb, including the pronominal prefix" (Ochola 2011: 18). Also see the case of the Nilotic language Lango (Velupillai 2012: 99, after Noonan 1992).

\subsubsection{Focus marked progressives}

Perhaps related to the Hungarian case in the next section is the case of the progressive expression through a focus marker in a number of African languages originally discussed in Hyman \& Watters (1984), who report for Efik "It is interesting to note that the only place in the tense system where there is an opposition between progressive and non-progressive aspect is in the [+focus] present tense. [..] In the [+focus] present tense [..] /- $m V-/$ unambiguously signals present perfect, while /ké-/ [a focus marker] signals present progressive." (p. 246). They also add that "the Haya focus marker ní similarly derives a progressive from a zero present tense." (p. 247). For more extensive documentation of focus marked progressives in Bantu, and in other language families, see Güldemann (2003) and Nurse (2006).

\subsubsection{Word order marked progressives (possibly due to $V(P)$ raising to a silent progressive projection)}

Hansen (2012: $\$ 4.3$ ) reports that Tikar, a Benue-Congo language spoken in Cameroon, exhibits a word order alternation that distinguishes between progressive and habitual aspect:

(80) a. à ta ken' fumban

(SVLoc; habitual) 3sG IMPF.NPST leave Foumban

'He is in the habit of leaving for Foumban.'

b. à ta fumban kenni'

(SLocV; progressive) 3sG IMPF.NPST Foumban leave

'He is in the process of leaving for Foumban.'

She reports that "[a]nother example of word order correlating with the progressive aspect can be found in Kokama-Kokamilla, a Tupí language spoken in the Peruvian Amazon as well as by a few small groups in Brazil and Colombia" (p. 297).

Bertinetto et al. (2000: 525) similarly report that in Hungarian "word order with a specific intonation contour of the clause allows for a progressive interpretation" citing the following contrast, where "indicates focal stress and ' neutral stress (note the different order of the verb with respect to the particle): 

a. Mari "le-vitte a bort, amikor csengetnek
Mary down-carried the wine, when ring:3sG
'Mary carried down the wine when the doorbell rang'
b. Mari 'vitte 'le a bort, amikor csengetnek
Mary carried down the wine, when ring:3sG
'Mary was carrying down the wine when the doorbell rang'

\subsubsection{No special morphology for the Progressive}

In other cases still (Bulgarian, ${ }^{61}$ Ndengeleko, ${ }^{62}$ and the Àhàn dialect of Yoruba) ${ }^{63}$ there is no differentiated expression of Progressive from Imperfect aspect, both conveyed by the present or the past imperfective form.

\subsection{A possible implication of the cross-linguistic encoding of Progressive aspect}

If we consider the many divergent ways just seen in which languages encode Progressive aspect, it seems difficult to reconstruct a unique paraphrase (containing both overt and silent elements) that may combine, in specifier position, all the different means with which languages express the Progressive aspectual category. Rather, what seems to be happening is that languages recruit different lexical items or morphology at their disposal to render in approximation, or rather evoke, different aspects of the semantic characterization of the Progressive ('be at', 'be with', 'be in the middle/midst of', 'do', 'be in the course of', 'be on the way', 'now', 'hold', 'engaged/busy in', 'during', etc.), but may also use means (tone, focus, clitics, reduplication, non trasparent particles or affixes) which do not even try to approximate aspects of that notion. ${ }^{64}$ If Progressive aspect is a universal category

61. See (34) and (35) above and the related text discussion. Nonetheless the Bulgarian Present is incompatible with instantaneous achievements ('find a wallet') and displays the same coercions with semelfactives (iterative interpretation) and ordinary achievements (prospective interpretation) as the progressive periphrasis in Italian and English.

62. "Ndengeleko does not distinguish between progressive and simple present" (Ström 2013: 231 footnote 114).

63. "Olumuyiwa (2012) accounts for three aspectual markers in the Moba dialect of Yoruba which he identifies as the $i$ (progressive), mọ $i$ (habitual) and $t i$ (perfective). Àhàn does not have any separate marker for progressive marker, the language marks time difference between habitual and perfective aspects" (Ogunmodimu 2013).

64. The fact that in some languages morphemes that are no longer transparent in meaning may be traced back to earlier more transparent sources (like the progressive no- prefix of Yagaria 'probably from hano 'to exist' - Bybee et al. 1994: 144) is beside the point. It only shows that 
(possibly reflecting the way our cognition analyses the world), a child only needs to recognize which piece of morphology represents it, even if this has no obvious correspondence to (parts of) its meaning. It may thus be tempting to assume that such complex abstract notions as Progressive (but also Habitual, Perfect, Prospective, Retrospective, ${ }^{65}$ etc.) are each a formal feature of the silent heads that head the core and the associated adverbial projections in whose specifiers the corresponding overt morphology is found, much in the way semanticists talk of a PROG, or a PAST, or a HAB operator (Dowty 1979; McClure 2008, among others). ${ }^{66}$

\section{Conclusion}

My conclusion is thus that the apparent segregation of overt phrases on one side of VP (and NP, AP, etc.) and of what were once analyzed as overt heads on the other side of VP (and NP, AP, etc.) does not warrant the conclusion that there are overt heads. The same result concerning this apparent segregation can be obtained by the segregation on one side of projections containing silent heads that select for a category distinct from their own and on the other side of all other projections. If so, heads can indeed be silent across the board (as in Kayne 2016) with possibly the specification that, in the case of clausal functional heads, they can be endowed with an abstract feature (+ progressive, +retrospective, +terminative, etc.), for which different languages recruit different lexical material to represent it

there is no requirement for an abstract complex notion like Progressive to be morphologically expressed in a way that transparently encodes (parts of) its complex meaning.

65. Like Progressive aspect, Retrospective aspect is rendered in different ways. In French by the verb venir de 'come from' with the optional adverb à peine (Il vient à peine de terminer son discourse - lit. He comes just from finish ${ }_{\text {infinitive }}$ his speech 'He has just finished his speech' Cinque 1999: 208 note 56); in Spanish by the verb acabar 'finish' (lo acabo de ver - lit. him I.finish of to.see 'I have just seen him'); in English, Italian and German by adverbs (just, appena and gerade, which may modify a silent 'now') (also see Cinque 1999: $₫ 4.19$ and references cited there); in Baba Malay by an adverb/adjective meaning 'new(ly)' (Lee 2014: $\$$ 5.2.5.3), in the Malayo-Polynesian language Paciran Javanese by the particle lagek "[whose] meaning can be enhanced with the marker (men)tas 'just now, a moment ago"'(Vander Klok 2012: 143); in the Austroasiatic Vietic language Kri by the particles kadang, kanaq 'just V-ed' (Enfield \& Diffloth 2009: $\$ 4.2$ ). For some of the many different ways in which also the Habitual aspect is encoded cross-linguistically see Carlson (2012).

66. Cf. also Timberlake (2007: 304). These features may also determine the precise position that the respective projection occupies in the functional hierarchy relative to other functional features/projections, whether the hierarchy (plausibly reflecting cognitive categories) is encoded in UG or is ultimately to be attributed to the CI interface. 
in the Specifier of the silent Core functional heads and/or in the Specifier of the associated adverbial projections.

\section{Acknowledgements}

A preliminary version of this article was presented at the workshop "What's in a label" held at Villa Salmi, Arezzo (Italy), from September 29 to October 1, 2016, and at the Scuola Normale Superiore in Pisa on May 19, 2017. For their comments I wish to thank Mark Baker, Jessica Coon, Norbert Corver, James Grimshaw, Pieter Muysken, Henk van Riemsdijk, Peter Svenonius, and Edwin Williams. I also thank Paola Benincà, Pier Marco Bertinetto, Richard Kayne, and Luigi Rizzi for discussion of some of the points raised here, and an anonymous reviewer for his/her helpful observations.

\section{References}

Abbott, Miriam. 1991. Macushi. Handbook of Amazonian Languages, Vol. 3, ed. by D. C. Derbyshire \& G. K. Pullum, 23-160. Berlin: De Gruyter Mouton.

Akumbu, Pius W. 2015. Babanki verb tone. Studies in African Linguistics 44.1: 1-26. Available at http://sal.research.pdx.edu/PDF/441Akumbu.pdf

Alamin, Suzan. 2012. The Nominal and Verbal Morphology of Tima: A Niger-Congo Language Spoken in the Nuba Mountains. Cologne: Rüdiger Köppe.

Ambe, Henry Suh Achuo. 1989. The Structure of Bafut (Volumes I and II). Washington (D.C.): Georgetown University.

Ameka, Felix K. 2002. The progressive aspect in Likpe: Its implications for aspect and word order in Kwa. New Directions in Ghanaian Linguistics: Essays in Honour of the 3Ds: M. E. Kropp Dakubu, Florence Abena Dolphyne, Alan Stewart Duthie, ed. by Felix K. Ameka \& E. Kweku Osam, 85-111. Accra: Black Mask Ltd.

Amman, Andreas. 2007. The fate of "redundant" verbal forms: Double perfect constructions in the languages of Europe. Sprachtypologie und Universalienforschung [Language Typology and Universals] 60.3: 186-204.

Arregui, Ana, María Luisa Rivero, \& Andrés Salanova. 2014. Cross-linguistic variation in imperfectivity. Natural Language and Linguistic Theory 32: 307-362.

doi: 10.1007/s11049-013-9226-4

Barbiers, Sief. 2000. The right periphery in SOV languages: English and Dutch. The Derivation of $V O$ and $O V$, ed. by Peter Svenonius, 181-218. Amsterdam: John Benjamins. doi: 10.1075/la.31.08bar

Bar-El, Leora Anne. 2005. Aspectual Distinctions in Skwxwú7mesh. Vancouver: University of British Columbia dissertation.

Benincà, Paola, \& Cecilia Poletto. 1994. Bisogna and its companions: the verbs of necessity. Paths Towards Universal Grammar: Studies in Honor of Richard S. Kayne, ed. by Guglielmo Cinque, Jan Koster, Jean-Yves Pollock, Luigi Rizzi \& Raffaella Zanuttini, 35-57. Washington: Georgetown University Press. 
Bennett, Michael, \& Barbara Partee. 1972. Toward the logic of tense and aspect in English. Technical Report for the System Development Corporation. Santa Monica: System Development Corporation.

Berizzi, Mariachiara, \& Silvia Rossi. 2010. "Sure I'm after seeing him not five minutes ago" (J. Joyce): The After-Perfect construction in Hiberno-English. Quaderni di Lavoro ASIt [ASIt Working Papers]10: 19-37 Available at http://asit.maldura.unipd.it/documenti/ql10/3_ Berizzi_Rossi_ASIt10.pdf

Bertinetto, Pier Marco. 1986. Tempo, Aspetto e Azione nel Verbo Italiano: Il sistema dell'Indicativo [Tense, Aspect and Action in the Italian Verb: The Indicative System]. Firenze: L'Accademia della Crusca.

Bertinetto, Pier Marco. 2000. The progressive in Romance, as compared with English. Tense and Aspect in the Languages of Europe, ed. by Östen Dahl, 559-604. Berlin: Mouton de Gruyter. Available at http://linguistica.sns.it/QLL/QLL95/PMB_Romance_progressive.pdf

Bertinetto, Pier Marco, \& Denis Delfitto. 1996. L’ Espressione della progressività-continuità: un confronto tripolare (italiano, inglese e spagnolo) [The expression of progressivity-continuity: a typological contrast (Italian, English, and Spanish)]. Italiano e Dialetto nel Tempo: Studi di Grammatica Offerti a Giulio Lepschy [Italian and Dialect in Time: Grammar Studies Offered to Giulio Lepschy], ed. by Paola Benincà, Guglielmo Cinque, Tullio De Mauro \& Nigel Vincent, 45-66. Rome: Bulzoni.

Bertinetto, Pier Marco, Karen H. Ebert, \& Casper de Groot. 2000. The progressive in Europe. Tense and Aspect in the Languages of Europe, ed. by Östen Dahl, 517-558. Berlin: De Gruyter Mouton. Available at http://www.unibuc.ro/prof/zafiu_r/docs/2014/ noi/24_08_02_01Bertinetto_et_al_2000.pdf

Bertocci, Davide, \& Silvia Rossi. 2011. Perifrasi azionali ed aspettuali in alcune varietà piemontesi [Actional and aspectual periphrases in some piedmontese varieties]. Quaderni di Lavoro ASIt [ASIt Working Papers], ed. by Jacopo Garzonio, Studi sui Dialetti del Piemonte [Studies on the Dialects of Piedmont] 13: 49-70. Available at http://asit.maldura.unipd.it/ documenti/ql13/ASIt13_bertocci_rossi.pdf

Bhatia, Tej K. 1993. Punjabi: A Cognitive-Descriptive Grammar. London: Routledge.

Bhatt, Rajesh, \& Roumyana Pancheva. 2005a. Note 1. Aspect: An overview. Lecture note at LSA 130: The Syntax and Semantics of Aspect. Available at http://web.mit.edu/rbhatt/www/ lsa130/11.pdf

Bhatt, Rajesh, \& Roumyana Pancheva. 2005b. Note 2. The Perfect. Lecture note at LSA 130: The Syntax and Semantics of Aspect. Available at http://web.mit.edu/rbhatt/www/lsa130/12.pdf Biberauer, Theresa, Anders Holmberg, \& Ian Roberts. 2014. A syntactic universal and its consequences. Linguistic Inquiry 45.2: 169-225. doi: 10.1162/LING_a_00153

Binnick, Robert I. 1991. Time and the Verb: A Guide to Tense and Aspect. Oxford: Oxford University Press.

Blansitt, Edward L., Jr. 1975. Progressive Aspect. Working Papers on Language Universals 18: 1-34. Blensenius, Kristian. 2015. Progressive Constructions in Swedish. Gothenburg: University of Gothenburg dissertation. Available at https:/gupea.ub.gu.se/bitstream/2077/40179/4/gupea_2077_40179_4.pdf

Bolaños Quiñonez, Katherine Elizabeth. 2016. A Grammar of Kakua. Amsterdam: University of Amsterdam dissertation. Available at http://www.lotpublications.nl/Documents/433_cover.pdf

Bolinger, Dwight. 1971. The nominal in the progressive. Linguistic Inquiry 2: 246-250. 
Bon, Noëllie. 2014. Une Grammaire de la Langue Stieng: Langue en Danger du Cambodge et du Vietnam [A Grammar of the Stieng Language: An Endangered Language in Cambodia and Vietnam]. Lyon: University Lumière Lyon 2 dissertation. Available at http://theses.univlyon2.fr/documents/lyon2/2014/bon_n/pdfAmont/bon_n_these.pdf

Borchers, Dörter. 2008. A Grammar of Sunwar: Descriptive Grammar, Paradigms, Texts and Glossary. Leiden: Brill.

Bortolotto, Laura. 2015. Ordering restrictions in the syntax of relational adjectives in Italian. Rivista di Grammatica Generativa [Research in Generative Grammar] (RGG) 37: 17-34. Available at http://lear.unive.it/jspui/handle/11707/5269

Bortoluzzi, Maria. 1992. The progressive aspect: some problem areas in comparing English and Italian. Studi italiani di linguistica teorica e applicata 21: 179-197.

Boutwell, Richard Lee. 2000. Functional Universals of Tense-aspect-modality Morphology in SOV Languages. Arlington: University of Texas at Arlington thesis.

Brown, Lea. 2001. A Grammar of Nias Selatan. Sydney: University of Sydney dissertation. Available at https://ses.library.usyd.edu.au//bitstream/2123/12669/1/PLBrown_ Thesis_\%202001_re.pdf

Bybee, Joan, Revere Perkins, \& William Pagliuca. 1994. The Evolution of Grammar: Tense, Aspect, and Modality in the Languages of the World. Chicago: Chicago University Press.

Carlson, Greg. 2012. Habitual and Generic Aspect. The Oxford Handbook of Tense and Aspect, ed. by Robert I. Binnick, 828-851. New York: Oxford University Press.

Carolan, Elizabeth, \& Jessica Coon. 2015. Negation in Chuj progressives (and other evidence for the biclausal structure of progressives). Paper presented at the 2015 annual meeting of SSILA, January 8-11, 2015. Portland: the Hilton Portland \& Executive Tower. Available at http://citeseerx.ist.psu.edu/viewdoc/download?doi=10.1.1.731.1467\&rep=rep1\&type=pdf

Cerruti, Massimo. 2009. Strutture dell'italiano Regionale: Morfosintassi di una Varietà Diatopica in Prospettiva Sociolinguistica [Structures of Regional Italian: Morphosyntax of a Diatopic Variety in a Sociolinguistic Perspective]. Frankfurt am Main: Peter Lang.

Cerruti, Massimo. 2011. Note sulla grammaticalizzazione di perifrasi aspettuali [Notes on the grammaticalization of aspectual periphrases]. Quaderni di Lavoro ASIt [ASIt Working Papers], ed. by Jacopo Garzonio, Studi sui Dialetti del Piemonte [Studies on the Dialects of Piedmont] 13: 71-93. Available at http://asit.maldura.unipd.it/documenti/q113/ASIt13_cerruti.pdf

Chia, Emmanuel N. 1976. Kom Tenses and Aspects. Washington, DC: Georgetown University dissertation.

Chomsky, Noam. 1964. Current Issues in Linguistic Theory. The Hague: De Gruyter Mouton.

Chomsky, Noam. 1965. Aspects of the Theory of Syntax. Cambridge: The MIT Press.

Chomsky, Noam. 2013. Problems of Projection. Lingua 130:33-49.

doi: 10.1016/j.lingua.2012.12.003

Cinque, Guglielmo. 1999. Adverbs and Functional Heads: A Cross-linguistic Perspective. New York: Oxford University Press.

Cinque, Guglielmo. 2004. Issues in adverbial syntax. Lingua 114: 683-710. Available at http:// lear.unive.it/jspui/bitstream/11707/126/1/Issues\%20in\%20adverbial\%20syntax.pdf

Cinque, Guglielmo. 2009. The fundamental left-right asymmetry of natural languages. Universals of Language Today, ed. by Sergio Scalise, Elisabetta Magni \& Antonietta Bisetto, 165-184. Dordrecht: Springer. Available at http://lear.unive.it/jspui/bitstream/11707/99/1/ CINQUE\%201.pdf doi: 10.1007/978-1-4020-8825-4_9

Cinque, Guglielmo. 2010. Mapping Spatial PPs: An Introduction. Mapping Spatial PPs: The Cartography of Syntactic Structures, Vol. 6, ed. by Guglielmo Cinque \& Luigi Rizzi, 
3-25. Oxford: Oxford University Press. Available at http://lear.unive.it/jspui/bitstream/11707/142/1/Mapping\%20Spatial\%20PPs.pdf

doi: 10.1093/acprof:oso/9780195393675.003.0001

Cinque, Guglielmo. 2011. Greenberg's Universal 23 and SVO languages. Structures and Meanings: Cross- theoretical perspectives, ed. by Mara Frascarelli, 75-80. Turin: L'Harmattan. Available at http://lear.unive.it/jspui/bitstream/11707/569/2/2\%20Cinque.pdf

Cinque, Guglielmo. 2014. Again on tense, aspect, mood morpheme order and the 'Mirror Principle. Functional Structure from Top to Toe: The Cartography of Syntactic Structures, Vol. 9, ed. by Peter Svenonius, 232-265. New York: Oxford University Press. Available at http://lear.unive.it/jspui/bitstream/11707/131/1/Cinque.TAM.MirrorP.pdf doi: 10.1093/acprof:0so/9780199740390.003.0008

Cinque, Guglielmo. 2015. A note on 'other'. Charting the Landscape of Linguistics: Webschrift for Josef Bayer, ed. by Ellen Brandner, Anna Czypionka, Constantin Freitag \& Andreas Trotzke, 22-27. Konstanz: Universität Konstanz. Available at http://ling.uni-konstanz.de/ pages/WebschriftBayer/2015/title.html

Cinque, Guglielmo. 2017. A microparametric approach to the head-initial/head-final parameter. To appear in Parameters: what are they? Where are they? ed. by S. Karimi \& M. Piattelli Palmarini (Special issue of Linguistic Analysis). Available at http://lear.unive.it/jspui/handle/11707/6084

Cipria, Alicia, \& Craige Roberts. 2000. Spanish imperfect and préterito: Truth conditions and aktionsart effects in a situation semantics. Natural Language Semantics 8: 297-347. doi: 10.1023/A:1011202000582

Comrie, Bernard. 1976. Aspect. Cambridge: Cambridge University Press.

Coon, Jessica, \& Elizabeth Carolan. 2015. Nominalization and the structure of progressives in Chuj Mayan. Ms. Available at http://jessica.lingspace.org/wp-content/uploads/2015/04/ chujnominalizations.pdf

Copley, Bridget, \& Isabelle Roy. 2013. Deriving the readings of French être en train de. Paper presented at Going Romance Amsterdam November 28-30, 2013. Amsterdam: University of Amsterdam. Available at http://bcopley.com/wp-content/uploads/copley.roy_. eetd_.31march2014.ms_.pdf

Cordin, Patrizia. 1997. Tense, mood and aspect in the verb. The Dialects of Italy, ed. by Martin Maiden \& Mair Parry, 87-98. London: Routledge.

Corver, Norbert. 2008. On silent, semi-lexical PERSON. Lingue e Linguaggio 1: 5-24. Available at http://norbert.abelcorver.com/wp-content/uploads/2010/10/Corver-Semi-lexicalPERSON.pdf

Dahl, Östen. 1985. Tense and Aspect Systems. Oxford: Basil Blackwell. Available at http://www. su.se/polopoly_fs/1.251617.1444651289!/menu/standard/file/Tense\%26aspectsystems.pdf

Daly, John P. 1973. A Generative Syntax of Peñoles Mixtec. Norman: Summer Institute of Linguistics, University of Oklahoma.

Dauzat, Albert. 1954. A propos des temps surcomposés: surcomposé provençal et surcomposé français [Regarding the double-compound tenses: Provençal double-compound and French double-compound tenses]. Le Français Moderne 22: 259-262. Available at http:// www.le-francais-moderne.com/pages/archives-fm.html

Davies, William D. 2010. A Grammar of Madurese. Berlin: De Gruyter Mouton. doi: $10.1515 / 9783110224443$

Davis, Karen. 2003. A Grammar of the Hoava Language, Western Solomons. Canberra: Pacific Linguistics (The Australian National University). 
De Belder, Marijke. 2007. Silence and the construct state in Dutch date expressions. Linguistics in the Netherlands: 24.1: 25-35. Available at http://www.jbe-platform.com/content/journals/10.1075/avt.24.05de

de Groot, Casper. 2000. The absentive. Tense and Aspect in the Languages of Europe, ed. by Östen Dahl, 641-667. Berlin: Mouton de Gruyter.

den Besten, Hans. 1989. Studies in West Germanic Syntax. Tilburg: University of Tilburg dissertation.

Derbyshire, Desmond C. 1986. Comparative survey of morphology and syntax in Brazilian Arawakan. Handbook of Amazonian Languages, Vol. 1, ed. by D. C. Derbyshire \& G. K. Pullum, 469-566. Berlin: De Gruyter Mouton. doi: 10.1515/9783110850819.469

De Wit, Astrid, \& Adeline Patard. 2012. The grammaticalization of the present progressive in French compared to English. Paper presented at the 45th Annual SLE meeting, August 28, 2012. Stockholm: Stockholm University. Available at http://uahost.uantwerpen.be/dewit/ Conf\%205\%20Stockholm.pdf

De Wit, Astrid, Adeline Patard, \& Frank Brisard. 2013. A contrastive analysis of the present progressive in French and English. Studies in Language 37.4: 846-879. Available at https:// www.researchgate.net/profile/Astrid_De_Wit

Dini, Luca. 2002. Events and Their Measures. Alessandria: Edizioni dell'Orso.

Do-Hurinville, Danh Thành. 2007. Etude sémantique et syntaxique de être en train de [Semantic and syntactic study of être en train de]. L'Information Grammaticale [Grammatical Information] 113: 32-39. Available at http://www.persee.fr/doc/igram_0222-9838_2007_ num_113_1_3884

Donaldson, B. C. 1981. Dutch Reference Grammar. The Hague: Martinus Nijhoff.

Dowty, David R. 1979. Word Meaning and Montague Grammar. Dordrecht: Kluwer. doi: 10.1007/978-94-009-9473-7

Dryer, Matthew S. 1992. The greenbergian word order correlations. Language 68.1: 81-138. doi: 10.1353/lan.1992.0028

Duffield, Nigel. 1999. Final modals, adverbs and antisymmetry in Vietnamese. Revue québécoise de linguistique 27.2: 92-129.

Duquesne, Emmanuel. 2013. "Haar drome is besig om waar te word": An Afrikaans Progressive Construction? Leuven: Catholic University of Leuven thesis. Available at https://www.academia.edu/19499161/The_Progressive_in_Afrikaans

Ebert, Karen H. 1995. Ambiguous perfect-progressive forms across languages. Temporal Reference, Aspect and Actionality, Vol. 2: Typological Perspectives, ed. by Pier Marco Bertinetto, Valentina Bianchi, Östen Dahl \& Mario Squartini, 185-203. Turin: Rosenberg \& Sellier.

Ebert, Karen H. 2000. Progressive markers in Germanic languages. Tense and Aspect in the Languages of Europe, ed. by Östen Dahl, 605-653. Berlin: Mouton de Gruyter. Available at https://user.phil-fak.uni-duesseldorf.de/ filip/Ebert\%202000.pdf

Elimelech, Baruch. 1978. A Tonal Grammar of Etsako. Berkeley: University of California Press.

Embick, David, \& Roumyana Izvorski. 1995. Participle-auxiliary word-orders in Slavic. Formal Approaches to Slavic Linguistics: The Cornell Meeting, ed. by Wayles Browne, 210-239. Ann Arbor: Michigan Slavic Publications.

Emonds, Joseph E. 1985. A Unified Theory of Syntactic Categories. Dordrecht: Foris. doi: $10.1515 / 9783110808513$ 
Emonds, Joseph E. 1996. Secondary predication, stationary particles and silent prepositions. Essays in Linguistics and Philology Presented to Professor Kinsuke Hasegawa, ed. by Akira Baba et al., 1-20 Tokyo: Kenkyusha Press.

Enfield, N. J., \& Gérard Diffloth. 2009. Phonology and sketch grammar of Kri, a Vietic language of Laos. Cahiers de Linguistique - Asie Orientale 38.1: 3-69. Available at http://pubman. mpdl.mpg.de/pubman/item/escidoc:107912/component/escidoc:204877/Enfield_2009_ Phonology+and+sketch+grammar+of+Kri.pdf

Fagard, Benjamin. 2003. Après: de l'espace au temps, la sémantique en diachronie [After: from space to time, semantics in diachrony]. Linguagem, Cultura e Cognição [Language, Culture and Cognition], Jul 2003, Braga, Portugal. <halshs-01242130> HAL Open Access Archive, 231-246. Available at https://halshs.archives-ouvertes.fr/halshs-01242130/document

Filppula, Markku. 1999. The Grammar of Irish English: Language in Hibernian Style. London: Routledge.

Forner, Werner. 1997. Liguria. The Dialects of Italy, ed. by Martin Maiden \& M. Mair Parry, 245-252. London: Routledge.

Frajzyngier, Zygmunt, Marion Bond, Lori Heintzelman, Dan Keller, Saeko Ogihara, \& Erin Shay. 2008. Towards an understanding of the progressive form in English: the Imperative as a heuristic tool. Modality-Aspect Interfaces: Implications and Typological Solutions, ed. by Werner Abraham \& Elisabeth Leiss, 81-96. Amsterdam: John Benjamins. doi: $10.1075 /$ tsl.79.08fra

Franco, Ludovico. 2013. On the syntax of Pantiscu aspectual subject clitics. Ms., CLUNL/FCSH/ Universidade Nova de Lisboa.

GLR = Gramatica Limbii Române [Grammar of the Romanian Language] Vol.II, 2005. Bucharest: Academiei Romane [The Romanian Academy Publishing House].

Gold, Elaine. 2007. Aspect in Bungi: expanded progressives and be perfects. Proceedings of the 2007 Annual Conference of the Canadian Linguistic Association, ed. Milica Radišić, 11 pages. Available at http://homes.chass.utoronto.ca/ cla-acl/actes2007/Gold.pdf

Grangé, Philippe. 2013. Aspect in Indonesian: free markers vs bound markers. Tense, Aspect, Mood and Evidentiality in Languages of Indonesia. NUSA 55: 57-79. Available at http:// repository.tufs.ac.jp/handle/10108/74326

Greenberg, Joseph H. 1963. Some universals of grammar with particular reference to the order of meaningful elements. Universals of Language, ed. by Joseph H. Greenberg, 73-113. Cambridge: The MIT Press.

Güldemann, Tom. 2003. Present progressive vis-à-vis predication focus in Bantu. Studies in Language 27.2: 323-360. doi: 10.1075/sl.27.2.05gul

Haegeman, Liliane M. V. 1982. The futurate progressive in Present-Day English. Journal of Linguistic Research 2: 13-19.

Haider, Hubert. 1992. Branching and discharge. Lexical Specifications and Insertion, ed. by Peter Coopmans, Martin B. H. Everaert \& Jane Grimshaw, 135-164. Amsterdam: John Benjamins.

Haider, Hubert. 2013. Symmetry Breaking in Syntax. Cambridge: Cambridge University Press. Haiman, John. 2011. Cambodian: Khmer. Amsterdam: John Benjamins. doi: 10.1075/loall.16

Hansen, Cynthia I. A. 2012. Exploiting syntax to circumvent morphology: word order as a means for marking grammatical categories. Language Documentation and Description, Vol. 10: Special Issue on Humanities of the Lesser-known: New Directions in the Description, Documentation and Typology of Endangered Languages and Musics, ed. by Niclas Burenhult, 
Arthur Holmer, Anastasia Karlsson, Håkan Lundström \& Jan-Olof Svantesson, 288-306. London: SOAS. Available at http://www.elpublishing.org/docs/1/10/ldd10_13.pdf Harrison, Sheldon P. 1976. Mokilese Reference Grammar. Honolulu: University of Hawai' i Press. Hawkins, Jack. A. 1983. Word Order Universals. New York: Academic Press.

Heine, Bernd, \& Tania Kuteva. 2002. World Lexicon of Grammaticalization. Cambridge:

Cambridge University Press. doi: 10.1017/CBO9780511613463

Higginbotham, James. 2004. The English progressive. The Syntax of Time, ed. by Jacqueline Guéron \& Jacqueline Lecarme, 329-358. Cambridge: The MIT Press.

Holton, Gary. 2014. Western Pantar. The Papuan Languages of Timor, Alor and Pantar Vol. 1: Sketch Grammars, ed. by Antoinette Schapper, 23-96. Berlin: De Gruyter Mouton.

Horvath, Julia. Forthcoming. Pied-Piping. To appear in The Wiley Blackwell Companion to Syntax (2nd edition), ed. by Martin Everaert \& Henk C. van Riemsdijk. Hoboken: Wiley-Blackwell. Hualde, Jose Ignacio, \& Jon Ortiz de Urbina. 1987. Restructuring with ARI. ASJU International Journal of Basque Philology XXI-2: 425-452.

Hyman, Larry M., \& John R. Watters. 1984. Auxiliary focus. Studies in African Linguistics 15.3: 233-273. Available at http://journals.linguisticsociety.org/elanguage/sal/article/ download/1168/1168-1729-2-PB.pdf

Hyslop, Catriona. 2001. The Lolovoli Dialect of the North-East Ambae Language: Vanuatu. Canberra: Asia-Pacific Linguistics.

Inagaki, Kazuya. 2013. TAME indicators in Kadorih. Tense, Aspect, Mood and Evidentiality in Languages of Indonesia. NUSA 55: 95-121, ed. by John Bowden. Available at http://hdl. handle.net/10108/74328

Jäger, Andreas. 2006. Typology of Periphrastic 'Do'-Constructions. Bochum: Universitätsverlag Dr. N. Brockmeyer.

Jendraschek, Gerd. 2006. Basque in contact with Romance languages. Grammars in Contact: A Cross-Linguistic Typology, ed. by Alexandra Y. Aikhenvald \& R. M. W. Dixon, 143-162. Oxford: Oxford University Press.

Jespersen, Otto. 1924. The Philosophy of Grammar. London: Allen \& Unwin Ltd.

Kawasha, Boniface Kaumba. 2003. Lunda Grammar: A Morphosyntactic and Semantic Analysis. Eugene: University of Oregon dissertation.

Kayne, Richard S. 1975. French Syntax: The Transformational Cycle. Cambridge: The MIT Press. Kayne, Richard S. 1994. The Antisymmetry of Syntax. Cambridge: The MIT Press.

Kayne, Richard S. 1999. Prepositional complementizers as attractors. Probus 11:39-73 (Reprinted in 2000, Parameters and Universals, 282-313. New York: Oxford University Press).

Kayne, Richard S. 2003a. Antisymmetry and Japanese. English Linguistics 20: 1-40 (Reprinted in 2005, Movement and Silence, 215-240. New York: Oxford University Press)

Kayne, Richard S. 2003b. Silent years, silent hours. Grammar in Focus: Festschrift for Christer Platzack 18 November 2003 Vol II, ed. by L.-O. Delsing, C. Falk, G. Josefsson \& H. Á. Sigurðsson, 209-226. Lund: Wallin \& Dalholm.

Kayne, Richard S. 2004. Here and There. Lexique, Syntaxe et Lexique-Grammaire / Syntax, Lexis and Lexicon-Grammar: Papers in Honour of Maurice Gross, ed. by Christian Leclère, Éric Laporte, Mireille Piot \& Max Silberztein, 275-285. Amsterdam: John Benjamins. Also in 2005, Movement and Silence. New York: Oxford University Press. doi: 10.1075/lis.24.23kay

Kayne, Richard S. 2005. Some notes on comparative syntax, with special reference to English and French. The Oxford Handbook of Comparative Syntax, ed. by Guglielmo Cinque \& Richard S. Kayne, 3-69. New York: Oxford University Press (Reprinted in 2005, Movement and Silence, 277-334. New York: Oxford University Press). 
Kayne, Richard S. 2006. On parameters and on principles of pronunciation. Organizing Grammar: Linguistic Studies in Honor of Henk van Riemsdijk, ed. by Hans Broekhuis, Norbert Corver, Riny Huybregts, Ursula Kleinhenz \& Jan Koster, 289-299. Berlin: De Gruyter Mouton (Reprinted in 2010. Comparisons and Contrasts, 73-81. New York: Oxford University Press). doi: 10.1515/9783110892994.289

Kayne, Richard S. 2016. The silence of heads. Studies in Chinese Linguistics 37.1: 1-37. Available at http://www.degruyter.com/downloadpdf/j/scl.2016.37.issue-1/scl-2016-0001/scl-20160001.xml

Kluge, Angela. 2017. A Grammar of Papuan Malay. Berlin: Language Science Press. Available at http://langsci-press.org/catalog/book/78

König, Ekkehard. 1995. He is being obscure: non-verbal predication and the progressive. Temporal Reference, Aspect and Actionality, Vol. 2: Typological Perspectives, ed. by Pier Marco Bertinetto, Valentina Bianchi, Östen Dahl \& Mario Squartini, 155-167. Turin: Rosenberg \& Sellier.

Koopman, Hilda. 2015a. A Note on Huave morpheme ordering: Local dislocation or (generalized) U20? Ms., UCLA.

Koopman, Hilda. 2015b. Generalized U20 and morpheme order. Ms., UCLA.

Koopman, Hilda, \& Anna Szabolcsi. 2000. Verbal Complexes (Current Studies in Linguistics Series 34). Cambridge: The MIT Press.

Kortmann, Bernd. 2004. Do as a tense and aspect marker in varieties of English. Dialectology Meets Typology: Dialect Grammar from a Cross-Linguistic Perspective, ed. by Bernd Kortmann, 245-276. Berlin: De Gruyter Mouton.

Kranich, Svenja. 2010. The Progressive in Modern English: A Corpus-Based Study of Grammaticalization and Related Changes. Amsterdam: Rodopi. doi: 10.1163/9789042031449

Kuteva, Tania. 1998. Large linguistic areas in grammaticalization: auxiliation in Europe. Language Sciences 20.3: 289-311. doi: 10.1016/S0388-0001(98)00005-9

Kuteva, Tania A. 1999. On 'sit'/'stand'/'lie' auxiliation. Linguistics 37.2: 191-213. Available at http://perso.univ-lille3.fr/ mlemmens/students/lai/Kuteva1999.pdf

Laca, Brenda. 2004. Les catégories aspectuelles à expression périphrastique: une interprétation des apparentes "lacunes" du français [Periphrastic aspectual categories: towards an interpretation of some apparent "gaps" in French]. Langue Française 141.1: 85-98.

Lachaux, Françoise. 2005. La périphrase être en train de, perspective interlinguale (anglaisfrançais): une modalisation de l'aspect? [The periphrase être en train de, interlingual perspective (English-French): a modalization of aspect?]. Les Periphrases Verbales [Verbal Periphrasis], ed. by Hava Bat-Zeev Shyldkrot \& Nicole Le Querler, 119-142. Amsterdam: John Benjamins. doi: 10.1075/lis.25.10lac

Laka, Itziar. 2006. Deriving split ergativity in the progressive: the case of Basque. Ergativity: Emerging Issues, ed. by A. Johns, D. Massam \& J. Ndayiragije, 173-196. Dordrecht: Springer. Available at http://www.ehu.eus/HEB/Itziar/DERIVINGERGATIVITYPROGRESSIVE06. pdf doi: 10.1007/1-4020-4188-8_7

Lambova, Mariana. 2004. On Information Structure and Clausal Architecture: Evidence from Bulgarian. Storrs: University of Connecticut dissertation.

LaPolla, Randy J. 2003. Qiang. The Sino-Tibetan Languages, ed. by Graham Thurgood \& Randy J. LaPolla, 573-587. London: Routledge.

Ledgeway, Adam. 2016. The dialects of southern Italy. The Oxford Guide to Romance Languages, ed. by Adam Ledgeway \& Martin Maiden, 246-269. Oxford: Oxford University Press. doi: 10.1093/acprof:0so/9780199677108.003.0016 
Lee, Nala Huiying. 2014. A Grammar of Baba Malay with Sociophonetic Considerations. Honolulu: University of Hawai'i at Mānoa dissertation. Available at http://ling.hawaii.edu/ wp-content/uploads/NalaHuiyingLeeFinal.pdf

Leeman, Danielle. 2012. Contribution à la définition de l'identité de la périphrase être en train de [Contribution to the definition of the identity of the periphrasis être en train de]. La Tribune Internationale des Langues Vivantes [The International Tribune of Modern Languages], 133138. Paris: Union des professeurs de langues dans les grandes écoles scientifiques. Available at https://halshs.archives-ouvertes.fr/halshs-00920705/document

Lehmann, Winfred P. 1978. The great underlying ground plans. Syntactic Typology: Studies in the Phenomenology of Language, ed. by Winfred P. Lehmann, 3-56. Austin: University of Texas Press.

Leu, Thomas. 2008. The Internal Syntax of Determiners. New York: New York University dissertation. Available at http://ling.auf.net/lingbuzz/000745

Leyew, Zelealem. 2012. The Kulisi Agaw: The People and Their Language. Addis Ababa: Addis Ababa University thesis. Available at http://www.uni-koeln.de/gbs/Berichte/Leyew_Kulisi. pdf

Litamahuputty, Betty. 2012. Ternate Malay: Grammar and Texts. Leiden: Universiteit Leiden dissertation. Available at http://www.lotpublications.nl/Documents/306_fulltext.pdf

Livingston, Andrew. 2016. East Uvean: A Condensed Grammar. Seattle: University of Washington thesis. Available at https://digital.lib.washington.edu/researchworks/handle/1773/3716.

Loporcaro, Michele. 2012. A new strategy for progressive marking and its implications for grammaticalization theory: the subject clitic construction in Pantiscu. Studies in Language 36.4: 747-784. doi: 10.1075/sl.36.4.02lop

Lynch, John. 1982. Anejom grammar sketch. Papers in Linguistics of Melanesia 4: 93-154.

MacDonald, Lorna. 1985. A Grammar of Tauya. Winnipeg: University of Manitoba dissertation. Available at http://mspace.lib.umanitoba.ca/handle/1993/28801

Marchand, Hans. 1955. On a question of aspect: a comparison between the progressive form in English and that in Italian and Spanish. Studia Linguistica 9.1-2: 45-52. doi: 10.1111/j.1467-9582.1955.tboo516.x

McClure, William. 2008. Morpho-semantics of the progressive. Proceedings of the 26th West Coast Conference on Formal Linguistics, ed. by Charles B. Chang \& Hannah J. Haynie, 384-392. Somerville: Cascadilla. Available at http://www.lingref.com/cpp/wccfl/26/paper1694.pdf

Montague, Richard. 1970. English as a formal language. Linguaggi nella Società e nella Tecnica [Languages in Society and Technology], ed. by B. Visentini, 189-224. Milan: Edizioni di Comunità [Community Editions] (reprinted in Formal Philosophy: Selected Papers of Richard Montague, ed. by H. Thomason, 108-221. New Haven: Yale University Press.)

Mortier, Liesbeth. 2008. An analysis of progressive aspect in French and Dutch in terms of Variation and Specialization. Languages in Contrast 8.1: 1-20. doi: 10.1075/lic.8.1.02mor

Nash, Lea, \& Alain Rouveret. 1997. Proxy Categories in Phrase Structure Theory. Proceedings of NELS 27, 287-304. Amherst: GLSA Publications.

Nchare, Abdoulaye Laziz, \& Arhonto Terzi. 2014. Licensing silent structure: the spatial prepositions of Shupamem. Natural Language \& Linguistic Theory 32.2: 673-710.

doi: 10.1007/s11049-014-9230-3

Noonan, Michael. 1992. A Grammar of Lango. Berlin: De Gruyter Mouton. doi: $10.1515 / 9783110850512$

Nurse, Derek. 2006. Focus in Bantu: verbal morphology and function. ZAS Papers in Linguistics 43: 189-207. Available at http://www.zas.gwz-berlin.de/fileadmin/material/ZASPiL_ Volltexte/zp43/zaspil43-nurse.pdf. 
Nurse, Derek. 2008. Tense and Aspect in Bantu. Oxford: Oxford University Press.

Oa, Morea, \& Ma'oni Paul. 2013. Tentative Grammar Description for the Gabadi language spoken in Central Province. Ukarumpa: SIL. Available at https://www.sil.org/resources/archives/56178.

Ochola, Elizabeth. 2011. Dholuo Morphosyntactics in a Minimalist Program: An Analysis of the Verbal System. Saarbrücken: LAP Lambert.

Ogunmodimu, Morakinyo. 2013. Tense, Aspect and Negation in Àhàn. Paper presented at the 2013 Hawaii University International Conferences Arts, Humanities, \& Social Sciences, January 6-8, 2013. Honolulu: Ala Moana Hotel. Available at http://www.huichawaii.org/ assets/ogunmodimu_morakinyo_ahs_2013.pdf

Olumuyiwa, Temitope. 2012. Tense-Aspect and Negation in Mọ̀bà. California Linguistic Notes Volume XXXVII No. 2: 1-12. Available at http://english.fullerton.edu/publications/clnArchives/pdf/Olumuyiwa-TenseAspectMoba.pdf.

Osumi, Midori. 1995. Tinrin Grammar. Honolulu: University of Hawai'i Press.

Overall, Simon E. 2007. A Grammar of Aguaruna. Melbourne: La Trobe University dissertation. Available at http://researchonline.jcu.edu.au/28174/1/28174-overall-2007-thesis.pdf

Pan, Chia-jung. 2012. A Grammar of Lha'alua, an Austronesian Language of Taiwan. Cairns: James Cook University dissertation. Available at http://researchonline.jcu.edu.au/32386

Pearce, Elizabeth. 2015. Completing and terminating: on aspect marking in Unua. The Languages of Vanuatu: Unity and Diversity, ed. by Alexandre François, Sébastien Lacrampe, Michael Franjieh \& Stefan Schnell, 23-52. Canberra: Asia-Pacific Linguistics. Available at http:// alex.francois.free.fr/data/Francois-et-al_2015_Languages-of-Vanuatu_SLIM.pdf

Piotrowska, C. M. 2014. A Diachronic Analysis of the Progressive Aspect in Black South African English. Potchefstroom: North-West University dissertation. Available at https://dspace. nwu.ac.za/handle/10394/14711

Poletto, Cecilia. 1993. The aspect projection: an analysis of the Passé Surcomposé. Proceedings of the XVIII Meeting of Generative Grammar, ed. by E. Fava, 289-312. Turin: Rosenberg \& Sellier.

Poletto, Cecilia. 2008. Syntactic encoding of aspect in some Northern Italian dialects. Tiempos Compuestos y Formas Verbales Complejas [Complex Tenses and Complex Verbal Forms], ed. by Ángeles Carrasco Gutiérrez, Chapter 11. Frankfurt-Madrid: Vervuert-Iberoamericana.

Poletto, Cecilia. 2009. Double auxiliaries, anteriority and terminativity. The Journal of Comparative Germanic Linguistics 12.1: 31-48. doi: 10.1007/s10828-009-9024-x

Portner, Paul. 2011. Perfect and progressive. Semantics: An International Handbook of Natural Language Meaning, Vol. 1, ed. by Claudia Maienborn, Klaus von Heusinger \& Paul Portner, 1217-1261. Berlin: De Gruyter Mouton. Available at http://www.semanticsarchive.net/ Archive/jlmMTE0M/Portner-perfect-progressive-HSK-draft.pdf

Prins, Maria Clazina. 2011. A Web of Relations: A Grammar of rGyalrong Jiǎomùzú (Kyom-kyo) Dialects. Leiden: Leiden University dissertation. Available at https://openaccess.leidenuniv. $\mathrm{nl} /$ bitstream/handle/1887/18157/front.pdf? sequence $=7$

Pusch, Claus D. 2003. La grammaticalisation de l'aspectualité: les périphrases à valeur progressive en français [The grammaticalisation of aspect: the periphrases with progressive value in French]. Verbum 4: 495-508.

Pustet, Regina, Juliana Wijaya, \& Than Than Win. 2006. Progressives in typological perspective. Languages in Contrast 6.2: 177-227. doi: 10.1075/lic.6.2.02pus

Rae, Megan. 2009. Ordering Restrictions of Modifiers in Complex Nominals. Venice: Ca' Foscari University of Venice dissertation. Available at http://lear.unive.it/jspui/handle/11707/331 
Ramchand, Gillian, \& Peter Svenonius. 2014. Deriving the functional hierarchy. Language Sciences 46: 152-174. doi: 10.1016/j.langsci.2014.06.013

Rastogi, Kavita. 2012. A Descriptive Grammar of Raji. Delhi: Aviram Prakashan.

Regmi, Dan Raj. 2012. Khwopa Newar: A Grammar Sketch. Munich: Lincom Europa.

Rizzi, Luigi. 2016. Labeling, maximality, and the head - phrase distinction. The Linguistic Review 33.1: 103-127. doi: 10.1515/tIr-2015-0016

Rohlfs, Gerhard. 1969. Grammatica Storica della Lingua Italiana e dei Suoi Dialetti [Historical Grammar of the Italian Language and of Its Dialects], Vol. 3: Sintassi e Formazione delle Parole [Syntax and Word Formation]. Turin: Einaudi.

Ronan, Patricia. 2012. Development of periphrastic tense and aspect constructions in Irish and Welsh. Grammaticalization and Language Change: New Reflections, ed. by Kristin Davidse, Tine Breban, Lieselotte Brems \& Tanja Mortelmans, 227-248. Amsterdam: John Benjamins. doi: 10.1075 /slcs.130.09ron

Ross, John Robert. 1967. Constraints on Variable in Syntax. Cambridge: The MIT dissertation. Saussure, Louis de, \& Bertrand Sthioul. 2012. The Surcomposé Past Tense. The Oxford Handbook of Tense and Aspect, ed. by Robert I. Binnick, 586-610. Oxford: Oxford University Press.

Schapper, Antoinette. 2009. Bunaq: A Papuan Language of Central Timor. Canberra: The Australian National University dissertation.

Schrock, Terrill B. 2014. A Grammar of Ik (Icé-tód): Northeast Uganda's Last Thriving Kuliak Language. Leiden: Universiteit Leiden dissertation. Available at https://openaccess.leidenuniv.nl/handle/1887/30201

Schubert, Silke. 2002. "Are you wanting a cup of coffee?”: Overuse of the progressive aspect in Indian English. Konstanz: Konstanzer Online-Publikations-System (KOPS). Available at https://kops.uni-konstanz.de/bitstream/handle/123456789/3793/Schubert_exam. pdf? sequence $=1$

Sharma, D. D. 1982. Studies in Tibeto-Himalayan Linguistics: A Descriptive Analysis of Pattani (a dialect of Lahaul). Hoshiarpur: Panjab University.

Sigurðsson, Halldór Ármann. 2004. Meaningful silence, meaningless sounds. Linguistic Variation Yearbook 4: 235-259. Available at https://ucris.lub.lu.se/ws/files/5203185/8500119.pdf

Sigurðsson, Halldór Ármann, \& Joan Maling. 2012. Silent heads. Functional Heads: The Cartography of Syntactic Structures, Vol. 7, ed. by Laura Brugé, Anna Cardinaletti, Giuliana Giusti, Nicola Munaro \& Cecilia Poletto, 368-378. New York: Oxford University Press. doi: 10.1093/acprof:oso/9780199746736.003.0028

Smith, Carlota S. 1983. A theory of aspectual choice. Language 59: 479-501. doi: 10.2307/413899

Smith, Carlota S. 1997. The Parameter of Aspect. (2nd edition). Dordrecht: Kluwer. doi: 10.1007/978-94-011-5606-6

So-Hartmann, Helga. 2009. A Descriptive Grammar of Daai Chin. Berkeley: Sino-Tibetan Etymological Dictionary and Thesaurus Project. Available at http://stedt.berkeley.edu/ pubs_and_prods/STEDT_Monograph7_Daai-Chin.pdf.

Soubrier, Aude. 2013. L'ikposso Uwi. Phonologie, Grammaire, Textes, Lexique [Ikposo Uwi: Phonology, Grammar, Texts, Lexicon]. Lyon: University Lumière Lyon 2 dissertation. Available at http://theses.univ-lyon2.fr/documents/lyon2/2013/soubrier_a/download

Squartini, Mario. 1998. Verbal Periphrases in Romance: Aspect, Actionality, and Grammaticalization. Berlin: De Gruyter Mouton. doi: 10.1515/9783110805291

Srioutai, Jiranthara. 2005. The (non-)progressive in Thai. Cambridge Occasional Papers in Linguistics 2: 211-235. Available at http://people.ds.cam.ac.uk/kmj21/srioutai2005.pdf 
Ström, Eva-Marie. 2013. The Ndengeleko Language of Tanzania. Gothenburg: University of Gothenburg dissertation. Available at https://gupea.ub.gu.se/handle/2077/32111

Svenonius, Peter. 2010. Spatial P in English. Mapping Spatial PPs: The Cartography of Syntactic Structures, Vol. 6, ed. by Guglielmo Cinque \& Luigi Rizzi, 127-160. Oxford: Oxford University Press. doi: 10.1093/acprof:0so/9780195393675.003.0004

Tamanji, Pius N. 2009. A Descriptive Grammar of Bafut. Cologne: Rüdiger Köppe.

Terzi, Arhonto. 2010. Locative prepositions and place. Mapping Spatial PPs: The Cartography of Syntactic Structures, Vol. 6, ed. by Guglielmo Cinque \& Luigi Rizzi, 196-224. Oxford: Oxford University Press. doi: 10.1093/acprof:oso/9780195393675.003.0006

Thurgood, Elzbieta. 1997. Bontok reduplication and prosodic templates. Oceanic Linguistics 36.1: $135-148$. doi: $10.2307 / 3623073$

Timberlake, Alan. 2007. Aspect, tense, mood. Language Typology and Syntactic Description, Vol. 3, ed. by Timothy Shopen, 280-333. Cambridge: Cambridge University Press. doi: 10.1017/CBO9780511618437.005

Tjia, Johnny. 2007. A Grammar of Mualang: An Ibanic Language of Western Kalimantan, Indonesia. Utrecht: LOT.

Todd, Terry Lynn. 1985. A Grammar of Dimili: Also Known as Zaza. Ann Arbor: University of Michigan. Available at http://www.zazaki.de/english/T.L.Todd-AGrammarofDimli.pdf

Utsumi, Atsuko. 2013. The system of tense and aspect in the Bantik language. Tense, Aspect, Mood and Evidentiality in Languages of Indonesia. NUSA 55: 219-237, ed. by John Bowden. Available at http://repository.tufs.ac.jp/bitstream/10108/74334/2/nusa5513.pdf

Vafaeian, Ghazaleh. 2012. Progressive constructions in Iranian languages. Proceedings of the Doctoral Festival 2012. Stockholm: Stockholm University.

van Klinken, Catharina Lumien. 1999. A Grammar of the Fehan Dialect of Tetun: An Austronesian Language of West Timor. Canberra: Pacific Linguistics (The Australian National University).

van Riemsdijk, Henk. 2002. The unbearable lightness of Going: The projection parameter as a pure parameter governing the distribution of elliptic motion verbs in Germanic. Journal of Comparative Germanic Linguistics 5: 143-196. Available at http://henk.villasalmi.it/ pub/2002\%20Unbearable\%20Lightness\%20of\%20GOing.pdf

van Riemsdijk, Henk. 2003. Some thoughts on specified ellipsis. Grammar in Focus: Festschrift for Christer Platzack 18 November 2003 Vol. II, ed. by L.-O. Delsing, C. Falk, G. Josefsson \& H. Á. Sigurðsson, 257-263. Lund: Wallin \& Dalholm.

van Riemsdijk, Henk. 2005. Silent nouns and the spurious indefinite article in Dutch. Grammar and Beyond: Essays in Honour of Lars Hellan, ed. by Mila Vulchanova \& Tor A. Åfarli, 163-178. Oslo: Novus Press.

van Riemsdijk, Henk. 2012. The absent, the silent, and the audible: some thoughts on the morphology of silent verbs. Of Grammar, Words, and Verses: In Honor of Carlos Piera, ed. by Esther Torrego, 19-39. Amsterdam: John Benjamins. Available at <<LINK:http://henk.villasalmi.it/pub/2012\%20to\%20app\%20Absent\%

Vander Klok, Jozina. 2012. Tense, Aspect, and Modal Markers in Paciran Javanese. Montréal: McGill University dissertation. Available at http://lingserver.arts.ubc.ca/linguistics/sites/ default/files/DissJVK_e-submission_dec15_0.pdf

Vander Klok, Jozina, \& Rose-Marie Déchaine. 2014. Stative versus Eventive Predicates and vPinternal Structure. Proceedings of the Annual Meeting of the Berkeley Linguistics Society 40: 545-569. Available at http://journals.linguisticsociety.org/proceedings/index.php/BLS/article/view/3157/2876 
Velupillai, Viveka. 2012. An Introduction to Linguistic Typology. Amsterdam: John Benjamins. doi: $10.1075 /$ z.176

Vendler, Zeno. 1957. Verbs and Times. The Philosophical Review 66.2: 143-160. Available at http://semantics.uchicago.edu/scalarchange/vendler57.pdf

Vennemann, Theo. 1973. Explanation in syntax. Syntax and Semantics, Vol. 2, ed. by John P. Kimball, 1-50. New York: Seminar Press.

Vinet, Marie-Thérèse. 1998. 'Tu pas': aspect et temps ['You not': aspect and tense]. Langues et Grammaire Vol.3: Syntaxe [Languages and Grammar Vol.3: Syntax], ed. by Patrick Sauzet, 181-195. Saint-Denis: Université de Paris VIII.

Watters, James Kenneth. 1988. Topics in Tepehua Grammar. Berkeley: University of California at Berkeley dissertation. Available at http://linguistics.berkeley.edu/ survey/documents/dissertations/watters-1988.pdf

Williams, Adina. 2016. Modificational and predicate adjunct uses of the Mandarin locative preposition zài. Paper presented at ConSOLE XXIV, January 6-8, 2016. York: University of York \& York St John University Available at https://wp.nyu.edu/adinawilliams/wp-content/ uploads/sites/2739/2015/09/ConsoleHandoutWilliams2.pdf

Williams, Edwin. 2003. Representation Theory. Cambridge: The MIT Press.

Winford, Donald. 2012. Creole Languages. The Oxford Handbook of Tense and Aspect, ed. by Robert I. Binnick, 428-457. Oxford: Oxford University Press.

Yanti. 2013. Tense and auxiliaries in Jambi Malay. Tense, Aspect, Mood and Evidentiality in Languages of Indonesia. NUSA 55: 239-257. Available at http://repository.tufs.ac.jp/bitstream/10108/74335/2/nusa5514.pdf

Zeitoun, Elizabeth, Lillian M. Huang, Marie M. Yeh, Anna H. Chang, \& Joy J. Wu. 1996. The temporal/aspectual and modal systems of the Formosan languages: a typological perspective. Oceanic Linguistics 35.1: 21-56. doi: 10.2307/3623029

Zobel, Erik. 2005. Buol. The Austronesian Languages of Asia and Madagascar, ed. by Alexander Adelaar \& Nikolaus P. Himmelmann, 625-648. London: Routledge.

\section{Author's address}

Guglielmo Cinque

Dipartimento di Studi Linguistici e Culturali Comparati

Università Ca' Foscari (University of Venice)

Dorsoduro 3246

30123 Venezia

Italy

cinque@unive.it

\section{Publication history}

Date received: 2 December 2016

Date accepted: 18 April 2017 